NBER WORKING PAPER SERIES

TAX POLICY AND INVESTMENT

Kevin A. Hassett

R. Glenn Hubbard

NBER Working Paper 5683

\author{
NATIONAL BUREAU OF ECONOMIC RESEARCH \\ 1050 Massachusetts Avenue \\ Cambridge, MA 02138 \\ July 1996
}

This paper was presented at the Conference on Fiscal Policy: Lessons from Economic Research, Robert D. Burch Center for Tax Policy and Public Finance, University of California, Berkeley, February 2-3, 1996. We are grateful to Josh Gillespie for excellent research assistance, and Alan Auerbach, Darrel Cohen, Jason Cummins, Bronwyn Hall, Charlie Himmelberg, Jim Kennedy, Sandy Struckmeyer, John Taylor, and conference participants for helpful comments and suggestions. This paper is part of NBER's research programs in Economic Fluctuations and Growth, and Public Economics. Any opinions expressed are those of the authors and not those of the Board of Governors of the Federal Reserve System, or the National Bureau of Economic Research.

(C) 1996 by Kevin A. Hassett and R. Glenn Hubbard. All rights reserved. Short sections of text, not to exceed two paragraphs, may be quoted without explicit permission provided that full credit, including $\odot$ notice, is given to the source. 


\title{
TAX POLICY AND INVESTMENT
}

\begin{abstract}
In this paper, we summarize recent advances in the study of effects of tax policy on the fixed investment decisions of firms. We attempt to identify consensus where it has been achieved and to highlight important unresolved issues. In addition, we discuss the implications of recent findings for the analysis of policy options, and discuss arguments for and against long-run tax policy that favors business investment spending.

Kevin A. Hassett

Stop 80

Board of Governors of the Federal Reserve System

Washington, DC 20551

R. Glenn Hubbard Graduate School of Business Columbia University 609 Uris Hall

New York, NY 10027 and NBER
\end{abstract}


"The first ship to arrive in St. Petersburg in 1701, a Dutch vessel, received from Peter the Great the privilege of paying no custom duties for the rest of its physical life -- a concession which had the effect of prolonging the ship's life for almost a century -- three or four times the normal span."

\section{Introduction}

Just as Peter the Great's tax amnesty spurred substantial maintenance investment in that Dutch ship, many governments have apparently believed that tax policy can be used as an instrument to alter firms' capital investment decisions. Indeed, investment tax credits (ITCs), special investment "reserve" funds, or accelerated depreciation allowances have been the rule rather than the exception in most developed countries since World War II. Against this backdrop, however, economists have generally struggled to find a significant impact of tax policy on investment.

The empirical economic literature on investment finds its early roots in the work of Aftalian (1909), Clark (1917), and Fisher (1930). Aftalian and Clark observed that business investment is highly correlated with changes in business output -- providing support for the early "accelerationist" school -- while Fisher's neoclassical theory argued for the importance of marginal conditions. At the risk of oversimplifying, the literature subsequently divided into two camps. One side argued that the "accelerator" model performed so well empirically that it should be adopted as the standard model, the other side looked to "neoclassical" models relating investment to the user cost of capital. While the neoclassical school may have had the theoretical high ground, empirical implementations of neoclassical models have been generally disappointing. Indeed, while the time-series evidence has always revealed that lags of output are highly correlated with investment, interest rates have

\footnotetext{
${ }^{1}$ See Braudel (1992, page 241).
} 
provided very limited additional explanatory power. ${ }^{2}$ The debate between these two schools provides a useful introduction to our review of the literature relating tax policy to investment. Many observers even recently (e.g., Clark, 1993) have argued that tax policy likely does not significantly affect investment, and the arguments inevitably harken back to the accelerationist debate.

Motivated by the hope that the simplest neoclassical models failed to explain investment fluctuations because they were too stylized, substantial energy was devoted to the task of extending these models to incorporate more realistic assumptions in the 1970 s and early 1980 s. $^{3}$ Chief among these was the incorporation of costs of adjusting the capital stock. According to these models, investment is forward-looking, and based upon rational expectations of future variables. Because firms base their expectations of future variables in part on their observations of the past, researchers identified a link between lagged variables and current investment. Indeed, correlation of past output growth and future "fundamentals" could be used to rationalize a strong correlation between current investment and past values of the growth of output. When asked to explain the time-series movements of investment, however, these new models proved very disappointing. Additional variables that were meant to capture the marginal cost or return to investment seemed to be of little use, over and above output, in predicting investment. Moreover, structural parameter estimates tended to be wildly implausible.

2 We update the time-series stylized facts in section III.

${ }^{3}$ Eisner and Strotz (1963) offer an early discussion of adjustment costs. The theory was developed and extended by Lucas (1967, 1976), Gould (1968), Treadway (1969, 1971), Uzawa (1969), Mortensen (1973), Abel (1980), and Hayashi (1982). Researchers have generally assumed convex costs of adjusting the capital stock; the idea is that it is more costly to implement a given increment to the capital stock quickly rather than gradually. We discuss alternative assumptions about adjustment costs in Section $\mathrm{V}$. 
It is at this point in the evolution of the literature that we begin this review. After briefly reviewing neoclassical theory, we summarize recent theoretical advances in section II. Section III updates the time-series stylized facts for investment. In Section IV, we review recent empirical studies of investment in producers' durable equipment. After concluding in section IV that tax policy designed to stimulate investment likely has done so, we turn in section $\mathrm{V}$ to the question of the desirability of such intervention, highlighting the arguments that have been made for and against stimulative tax policy. In section VI, we consider implications of our analysis for two current policy questions--whether lower inflation offers a significant investment stimulus and the consequences for investment of a switch from the current tax system to a broad-based consumption tax. Section VII concludes.

\section{Models of Investment in the Neoclassical Tradition}

Models in the neoclassical tradition focus on the derived demand for capital by valuemaximizing firms. ${ }^{4}$ This intuition is typically transformed into models of investment by making assumptions about costs of changing the capital stock. For simplicity of exposition, consider the decisions of a price-taking firm. Absent taxes, in each period $t$, firm $i$ 's real net cash flow is given by:

$$
X_{i, t}=F\left(K_{i, t-1}, N_{i, t}\right)-w_{t} N_{i, t}-p_{t} I_{i, t}-C\left(I_{i, t}, K_{i, t-1}\right),
$$

where $K(\bullet)$ is the capital stock, $F(\bullet)$ is the real revenue function of the firm, $N$ is the variable factor, $w$ is the price of the variable factor, $p$ is the real price of investment goods, and $C(\bullet)$ is the function

\footnotetext{
${ }^{4}$ For a more detailed discussion of the models introduced in this section, see Abel (1990).
} 
determining the cost of adjusting the capital stock. In the absence of taxes, then, the marginal cost of newly installed capital is $p_{t}+C_{l}\left(I_{i \mathrm{p}} K_{i, t-1}\right)$.

To study investment tax policy, we add to the net cash flow expression in (1) a profits tax at rate $\tau$, an investment tax credit at rate $k$, and the present value of a dollar's worth of depreciation allowances, $z .{ }^{5}$ With these additions, the marginal cost of newly installed capital is:

$$
p_{t}\left(1-\Gamma_{i, t}\right)+\left(1-\tau_{t}\right) C_{I}\left(I_{i, t}, K_{i, t-1}\right)
$$

where $\Gamma_{i t}=k_{i}+\mathrm{T}_{t} z_{i t}$, and we can rewrite (1) as:

$$
X_{i, t}=\left(1-\tau_{t}\right)\left(F\left(K_{i, t-1}, N_{t}\right)-w_{t} N_{i, t}-C_{I}\left(I_{i, t}, K_{i, t-1}\right)\right)-p_{t}\left(1-\Gamma_{i, t}\right) I_{i, t} .
$$

Under the assumption of value maximization, the firm maximizes the present value of its future net cash flows. Letting $\beta$ be the discount factor appropriate for the $i$ th firm the firm's value at time $t$, firm value is given by:

$$
V_{i, t}=\max E_{i, t} \sum_{s=t}^{\infty}\left(\stackrel{\Pi}{j=t}_{j}\right) \beta_{i, s} X_{s},
$$

where $E_{i t}$ is the expectations operator for firm $i$ conditional on information available at time $t$. The

${ }^{5}$ For the sake of simplifying the discussion, we focus here on the U.S. tax system. For a parallel analysis which employs a more general tax formulation which nests that of many countries see Sinn (1987), and King and Fullerton (1984). Sweden, in particular, has had one of the more complicated and interesting tax codes in the postwar period. For a discussion relating their code to this model see Taylor (1982), Södersten (1989), and Auerbach, Hassett, and Södersten (1995). 
firm chooses the path of investment and employment of the variable factor, given the initial capital stock, to maximize firm value. The change in the capital stock — net investment - is given by $I_{i t}$ $\delta K_{i, 1-1}$, where $\delta$ is the (assumed constant) proportional rate of depreciation.

For investment, the solution to the problem requires that the marginal value of an additional unit of investment equal its marginal cost. Denoting the shadow value of an additional unit of investment by $q:^{6}$

$$
q_{i, t}=p_{t}\left(1-\Gamma_{i, t}\right)+\left(1-\tau_{t}\right) C_{I}\left(I_{i, t}, K_{i, t-1}\right)
$$

The shadow price $q$ must also obey:

$$
\Delta q_{i, t}=\left(r_{i}+\delta\right) q_{i, t}-\left(1-\tau_{i}\right) F_{K}\left(K_{i, t-1}, N_{i, t}\right)+\left(1-\tau_{t}\right) C_{K}\left(I_{i, t}, K_{i, t-1}\right),
$$

where $r$ is the instantaneous rate at which marginal cash flows are discounted.

We can now use this general set up to examine two conventional formulations of the neoclassical approach, one based on the user cost of capital and one based on $q$.

\section{A. User Cost of Capital}

Jorgenson (1963) and his collaborators suggested using a form of equation (4) to derive an expression for the "user cost of capital." If we interpret $q$ as the price at which a unit of capital can be bought or sold, we can consider the thought experiment of renting a unit of newly installed capital. The owner of this capital will levy a rental cost $c$ such that the rate of return equals $r$, the return available on alternative (financial) assets. The owner's return from renting the capital equals

${ }^{6}$ Implicit in this derivation is the idea that firms can remove capital goods and sell them subject to an adjustment cost. 
the rental cost, $c$, plus the capital gain on the machine, $\Delta q_{i t+l} / q_{i t}$, less the depreciation of the machine, $\delta q_{i r}$. Expressed as a rate of return and equating the rate of return with the available alternative yields:

$$
c_{i, t}=\left(1-\tau_{t}\right)\left(r_{t}+\delta\right) q_{t}-\frac{\Delta q_{t}}{q_{i, t}}
$$

We can substitute for $q$ in equation (3) to express the user cost as a function of the price of investment goods, adjustment costs, and tax parameters. Jorgenson assumed that adjustment costs were zero, yielding the familiar user cost expression:

$$
c_{i, t}=p_{t}\left(\frac{1-\Gamma_{i, t}}{1-\tau}\right)\left(r_{t}+\delta-\frac{\Delta\left(p_{t+1}\left(1-\Gamma_{i, t}\right)\right.}{p_{t}\left(1-\Gamma_{i, t}\right)}\right),
$$

Returning to our derivation of $q$ in (3), we can more generally express the user cost as equaling the marginal cash flow of an additional unit of capital:

$$
\left(1-\tau_{t}\right)\left(F_{K}\left(K_{i, t-1}, N_{i, t}\right)-C_{K}\left(I_{i, t}, K_{i, t-1}\right)\right)=c_{i, t}
$$

Jorgenson's interest centered on isolating the effects of the user cost on the desired capital stock and investment. He considered a special case in which the prices $p, w$, and $r$ are constant and $I_{i t}=\delta K_{i, t-1}$ in steady state, (so that $C_{I}=C_{K}=0$ ). Hence from (7):

$$
\left(1-\tau_{t}\right) F_{K}\left(K_{i, t-1}, N_{i, 1}\right)=c_{i, t} \text {. }
$$


Assuming a constant elasticity of substitution production function:

$$
F(K, N)=A\left[b K^{-\theta}+(1-b) N^{-\theta}\right]^{-\frac{1}{\theta}},
$$

where $A>0,0<b<1$, and $\theta>-1$, one can express the marginal revenue product of capital as:

$$
F_{K}(K, N)=\left(\frac{b}{A^{\theta}}\right)\left(\frac{F}{K}\right)^{1+\theta}
$$

Returning to the Jorgensonian derivation in (7), the steady-state capital stock can be described as a function of the user cost of capital and the firm's real revenue:

$$
K^{*}=\left(\frac{b}{A^{\theta}}\right)^{\sigma} F \sigma\left(\frac{c}{1-\tau}\right)^{-\sigma}
$$

where $\sigma$ is the elasticity of substitution $(\sigma=1 /(1+\theta))$.

Equation (8) describes the steady-state capital stock, $K^{*}$. As we describe in more detail below, it is not an "estimating equation." To estimate investment, Jorgenson assumed that $\sigma=1$ (Cobb-Douglas technology), so that $K^{*}{ }_{i, i}=\left(b / A^{\theta}\right)\left[\left(I-\tau_{i}\right) F_{i} / c_{i, l}\right]$. He then assumed that the capital stock adjusted to the desired level at an exogenous rate dictated by, e.g. delivery lags. A substantial empirical debate ensued, with Eisner and Nadiri $(1968,1970)$ claiming on the one hand that the elasticity of substitution is nearer zero than unity, while Jorgenson and Stephenson (1969) claimed on the other hand that an elasticity of unity is more consistent with the data. ${ }^{7}$

7 It may be important to allow the ex ante and ex post values of $\sigma$ to be different, the argument being that the labor needed for a given piece of capital in place is fixed. This is the "putty-clay" hypothesis, put forward by Bischoff (1971). In some cases, these models have been shown to perform well empirically (see Struckmeyer, 1977). 
More contemporary applications of the user cost model incorporate explicit adjustment costs as opposed to ad hoc mechanism such as delivery lags. Auerbach (1989), for example, begins with the Euler equation for investment and assumes a production function with productivity shocks and adjustment cost function. He approximates the optimal solution for perturbations by solving a linearized version of the Euler equation. He then derives a relationship between the investment rate $\left(I_{i, 1} / K_{i, t-1}\right)$ and the user cost of capital, in which the user cost coefficient is a function of the steadystate average user cost and a root of the linearized difference equation in $K$ (for applications, see Auerbach and Hassett, 1991, 1992; and Cummins, Hassett, and Hubbard, 1994, 1996).

\section{B. The q Theory}

Tobin's (1969) $q$ theory of investment made more rigorous Keynes's (1936) idea that the incentive to add new fixed capital depends on the market value of capital relative to its replacement cost. Tobin represented by $q$ the ratio of the market value of the firm to the replacement cost of its capital stock. One can easily incorporate adjustment costs and tax parameters in the $q$ framework (see Hayashi, 1982).

Returning to equation (2), we know that equilibrium marginal $q$ is related to the price of investment goods, tax parameters, and adjustment costs. If we assume that the adjustment cost function is quadratic:

$$
C\left(I_{i, t}, K_{i, t-1}\right)=\frac{\omega}{2}\left(\frac{I_{i, t}}{K_{i, t-1}}-\mu_{i}\right)^{2} K_{i, t-1},
$$

where $\mu$ is the steady-state rate of investment and $\omega$ is the adjustment cost parameter, then equation (2) can be rewritten as an investment equation: 


$$
\frac{I_{i, t}}{K_{i, t-1}}=\mu_{i}+\frac{1}{\omega}\left[\frac{q_{i, t}-p_{t}\left(1-\Gamma_{i, t}\right)}{\left(1-\tau_{t}\right)}\right]
$$

Equation (10) offers a convenient way of estimating the responsiveness of investment to neoclassical variables, including tax parameters, but there is a hitch-marginal $q$ is unobservable. Following Hayashi (1982), if the firm is a price-taker in input and output markets, and the production function exhibits constant returns to scale, marginal $q$ equals average $q$, defined for each firm as tax-adjusted $q$ (denoted below by $Q$ ):

$$
Q_{i, t}=\frac{V_{i, t}+B_{i, t}-A_{i, t}}{K_{i, t-1}^{R}},
$$

where $V$ is the market value of the firm's equity, $B$ is the market value of the firm's debt, $A$ is the present value of depreciation allowances on investment made before period $t$, and $K^{R}$ is the replacement value of the firm's capital stock (including inventories).

The $Q$ formulation stresses a relationship between investment and the net profitability of investing, as measured by the difference between the value of an incremental unit of capital and the tax-inclusive cost of purchasing capital. As with the user cost approach, by making assumptions about costs of adjusting the capital stock, we can estimate effects of investment incentives on investment.

\section{Foreshadowing Empirical Problems}

Jorgenson (1963) investigated whether a version of equation (8) could be used to describe aggregate fluctuations in U.S. investment. Moving from this equilibrium relationship to an empirical 
model, however, required a few more steps. Because output is determined by the choice of $K$, equation (8) does not relate $K$ to a set of exogenous variables. ${ }^{8}$ Rather, it expresses a relationship between endogenous variables that holds in equilibrium. Indeed, equation (8) does not define an investment relationship, that is, the flow of capital, but rather describes only the equilibrium stock of capital. ${ }^{9}$ Jorgenson moved to an "investment" specification by defining a firm's "desired" capital stock, $K^{*}$ as $Y / c$, and then assuming that the firm gradually approached this desired stock over time. He assumed that the rate at which the firm closed the gap between its actual and desired stocks was given exogenously, and did not effect the level of the "desired" stock. These assumptions yielded the estimating equation:

$$
I_{t}=\sum_{i=0}^{T} \omega_{i}\left(K_{t-i}-K_{t-1-i}^{*}\right)+\delta K_{t-1}
$$

Hall and Jorgenson (1967) originally used such a model to explain aggregate investment, and concluded that it described the data well. Eisner and his collaborators later pointed out that the model they estimated -- recognizing that $K^{*}$ was the ratio of output to the user cost -- could be capturing accelerator effects, which had long been known to be strong explanatory factors for

8 To be more specific, Jorgenson assumed that the revenue function of the firm was CobbDouglas and that the firm set marginal revenue (with respect to capital) equal to the user cost in order to maximize profits.

${ }^{9}$ For example, Haavelmo (1960) writes "The demand for investment cannot simply be derived from the demand for capital...I think the sooner this naive, and unfounded theory of the demand for investment schedule is abandoned, the sooner we shall have a chance of making some real progress in constructing more powerful theories to deal with the capricious short-run variations in the rate of private investment." (quoted in Jorgenson, 1967, page 133) 
investment. In particular, if one constrained the user cost to be a constant, one could rewrite (12) as:

$$
I_{t}=\sum_{i=0}^{T} \omega_{i}\left(Y_{t-i}-Y_{t-1-i}\right)+\delta K_{t-1}
$$

which is a form of an accelerator model. When critics of Hall and Jorgenson isolated the separate contribution of the user cost to explaining investment, they found it to be negligible (see Eisner, 1969, 1970; Eisner and Nadiri, 1968; and Chirinko and Eisner, 1983).

Nonetheless, by the late 1960 s, the neoclassical model developed by Jorgenson and others had become the standard model for studying investment decisions, but empirical debates remained. On the one hand, the neoclassical approach offers a structural link between tax policy parameters - the corporate tax rate, the present value of depreciation allowances, and the investment tax credit - and investment through the user cost of capital. ${ }^{10}$ On the other hand, the empirical evidence suggested that the more rigorous theory did not improve the econometrician's ability to explain aggregate investment fluctuations or the response of business investment to changes in tax policy. Partially in response to this empirical concern, models based on the $Q$ representation of the firm's investment problem occupied much of the empirical research by the 1980 s. $^{11}$ A key appeal of the $Q$ approach was that it related investment to a variable that was (under certain assumptions) easier to observe than the user cost of capital. However, early empirical adaptation of $Q$ models did

${ }^{10}$ In an alternative representation, Feldstein (1982) explored the effects of effective tax rates on investment in reduced-form models; for a critique of this approach, see Chirinko (1987).

${ }^{11}$ As we noted earlier, Hayashi (1982) provided the conditions required to equate marginal $q$ with average $Q$, which is observable because it depends on the market valuation of the firm's assets. Summers (1981) incorporated additional tax parameters in the $Q$ model. 
not fare well in explaining either time-series or cross-sectional (firm-level) variation in investment.

Despite such empirical frustrations, policymakers in the United States and other industrial economies evidently believe that business fixed investment responds to tax changes - given the frequency with which they manipulate tax policy parameters. Hence it is disturbing that models emphasizing the net return to investing are defeated in forecasting "horse races" by ad hoc models and that structural variables are frequently found to be economically or statistically insignificant. ${ }^{12}$ Recently, the investment literature has begun to make a convincing case that the fundamentals are in fact key determinants of investment, but that they appear to have little effect in the macro data because of several severe econometric problems. ${ }^{13}$ To set the stage for the discussion of these problems in Section IV, we first review key "stylized facts" about the time-series behavior of business fixed investment and "fundamental determinants of investment."

\section{Some Stylized Facts about Business Fixed Investment}

In Figure 1, we plot aggregate U.S. equipment investment against several investment "fundamentals." The top panel shows the comovement of investment and the Jorgensonian user cost. The series rarely move together in an obvious way, and the correlation since 1960 is a statistically insignificant -0.11 . The second panel illustrates the strong comovements between investment and corporate cash flow. The two series are roughly coincident, and the correlation over time is a highly

${ }^{12}$ See, e.g., Bosworth (1985), Bernanke, Bohn, and Reiss (1988), and the survey in Chirinko (1993). The often poor empirical performance of $Q$ models has led some researchers to abandon the assumptions of reversible investment and convex costs used in testing neoclassical models in favor of approaches based on lumpy and "irreversible" investment. See, e.g., the discussions and reviews of studies in Pindyck (1991), Dixit and Pindyck (1994), and Hubbard (1994).

${ }^{13}$ Taylor (1993) does find, however, that aggregate fixed investment is significantly negatively related to the real interest rate in every one of the G7 countries. 
significant 0.64 . The bottom panel illustrates the "accelerator" effect, which relates changes in the growth rates of output and equipment spending. As with cash flow, the correlation is large and highly significant, and the coincidence of the series is visually striking.

While one should be cautious interpreting such correlations formally, they nonetheless suggest clear patterns. Aggregate equipment investment varies significantly over the business cycle, and neither lags or leads the cycle; it is highly correlated with other variables that are also highly procyclical. The time-series correlation between investment and the user cost, on the other hand, is quite weak. Figure 1 can be thought of as a visual summary of the early investment literature: Accelerator effects are strong and obvious; user cost effects appear weaker and more subtle.

We focus on studies of equipment investment, in large part beccause empirical attempts to model investment in structures have been more disappointing. Figure 2, which repeats Figure 1 with the relevant "fundamentals" related to the growth rate of investment in nonresidential structures, illustrates the problem. Structures investment is less clearly correlated with all of the "fundamentals." The correlation with the user cost is insignificant and has the incorrect sign, the correlation with cash flow is about one-fourth of that between cash flow and equipment investment, and the accelerator effect, while still noticeable, is significantly weaker.

An alternative branch of the investment literature has followed the suggestion of Tobin (1969) that investment should be related to $Q$, the ratio of the market value of the firm to the replacement costs of its capital stock. Figure 3 depicts the correlation of aggregate business fixed investment with $Q .{ }^{14}$ The top panel compares the level of real investment to the level of $Q$. Clearly,

14 The measure of $Q$ plotted here is constructed from data from the Federal Reserve's Flow of Funds Accounts. 
the low frequency movements in the two series are not highly correlated. The bottom panel relates the growth rates of these two series. Here it appears that growth in $Q$ leads growth in investment somewhat, although the relationship is weak, and the contemporaneous correlation is actually negative. ${ }^{15}$

To summarize, the tendency for a number of aggregate variables to move together over the business cycle makes it difficult to isolate effects of individual fundamentals on investment. Hence a partial equilibrium investment demand approach might have very little power to explain aggregate investment fluctuations. Movements of the aggregate variables -- including investment -- are determined simultaneously, and disentangling the marginal impact of a single driving variable is difficult if not impossible. For example, suppose that aggregate demand increases exogenously for some reason. This shift might lead firms to be more optimistic about their sales prospects and to purchase more investment goods; it might also be expected -- at least in the short run -- to lead to higher interest rates. If we then examine the correlation between investment and the interest rate, we might even find that the sign is the opposite of that predicted by the theory. While an instrumental variables procedure might allow us to overcome this simultaneity problem, the estimator is only as good as the instruments, and it is difficult to imagine an appropriate set of instruments for this application. Microeconomic data, however, provide a rich additional source of

is If we regress the growth rate of business fixed investment on many lags of the growth rate of $Q$, the sum of the coefficients is about 0.1 , implying that a 20 percent increase in the growth rate of $Q$ would lead to a prediction of about a 2 percent higher growth rate of business fixed investment. Cochrane (1992) finds significantly larger effects of the growth of $Q$ on the growth of total private investment. The results differ because Cochrane's measure of investment includes residential investment, which is -- perhaps surprisingly -- more highly correlated with stock market fluctuations. 
variation, and it is to the microdata studies that we now turn.

\section{Estimating Effects of Tax Policy on Investment Using Micro Data}

Standard investment models emphasizing the net return to investment yield four empirical representations. Each begins with the firm maximizing its net present value. The first-order conditions lead to an Euler equation describing the period-to-period optimal path of investment. Abel and Blanchard (1986) solved the difference equation that relates investment to its expected current and future marginal revenue products of capital; Gilchrist and Himmelberg (1994) apply a related forecasting approach to panel data. Alternatively, effects of tax parameters may be estimated from the Euler equation (see, e.g., Abel, 1980; and Hubbard and Kashyap, 1992). As in Auerbach (1983b) and Abel (1990), investment can be expressed in terms of current and future values of the user cost of capital and, under some conditions, expressed in terms of average $q$. Again, this approach was suggested initially by Tobin (1969), with the necessary conditions supplied by Hayashi (1982).

\section{A. The Basic Problem}

To assess recent empirical work on tax policy and investment, we begin with the following general model of investment, which follows the discussion in section II.

$$
\frac{I_{i, t}}{K_{i, t-1}}=S_{i, t} \gamma+\epsilon_{i, t}
$$

where $I$ and $K$ denote investment and the capital stock, respectively; $S$ is an underlying structural variable (e.g., the expected value of tax-adjusted $Q$ or the user cost of capital) or set of variables; $\gamma$ is a coefficient whose structural interpretation relates to assumptions about convex costs of adjusting 
the capital stock; and $\epsilon$ is a white-noise error term that reflects optimization error by firms. ${ }^{16}$

Researchers usually estimated such models using either ordinary least squares or generalized method of moments techniques with instrumental variables. Cummins, Hassett, and Hubbard (1994, 1996) note that conventional estimated values of $\gamma$ in firm-level panel data for the United States or for other countries are very small, ranging from 0.01 to 0.05 , implying marginal costs of adjustment of between one and five dollars per dollar of investment. Such estimates, which have emerged in many empirical studies (see, e.g., Summers, 1981; Salinger and Summers, 1983; and Fazzari, Hubbard, and Petersen, 1988a), imply very small effects of permanent investment incentives on investment.

Subsequently, empirical researchers have offered two general explanations of the failure to estimate significant tax effects on investment - (1) measurement error in fundamental variables, and (2) misspecification of costs of adjusting the capital stock. Both research programs have contributed to our understanding of the responsiveness of investment to changes in the net return to investing and have reached similar conclusions about the likely effects of tax policy for some important cases.

\section{B. Measurement Error in Fundamental Variables}

A major problem in using equation (14) in order to recover estimates of marginal adjustment costs and the effect of tax changes on investment is that measurement error in $Q$ or the user cost of capital may bias downward the estimated coefficient. A number of techniques have been suggested to address this measurement error, including: (1) statistical corrections, (2) avoiding the use of $Q$

\footnotetext{
${ }^{16}$ One could, of course, incorporate more complex error structures. We make this simplifying assumption for ease of exposition.
} 
or user cost representations, (3) using new proxies for $Q$, (4) focusing on periods or frequencies in which firm variation in fundamental variables is less subject to measurement error, and (5) modifying assumptions about the financial frictions firms face. We consider each in turn below and examine whether the techniques produce a "consensus" estimate of adjustment costs that can be used to forecast the effects of investment incentives on business fixed investment.

Statistical Approaches. There are at least two problems in measuring $Q$ that might affect estimated adjustment costs. First, to the extent that the stock market is excessively volatile, $Q$ might not reflect market fundamentals. Second, the replacement value of the capital stock in the denominator of $Q$ is likely to be measured with error. Griliches and Hausman (1986) argue that measurement error will lead to different biases among potential estimators that are similar in that they control for firm-specific effects, but differ in their signal-to-noise ratios, making it possible to place bounds on the importance of measurement error. Cummins, Hassett, and Hubbard (1994) estimate a model like (14) using first differences and longer differences (as opposed to the conventional fixed-effects, within-group estimator) to address measurement error problems. Their estimated adjustment costs decline significantly.

In a time-series setting, Caballero (1994) pursues an alternative estimation strategy, based on a suggestion by Stock and Watson (1993). Caballero argues that small sample biases of typically employed time-series estimation procedures are particularly severe when estimating adjustment cost models, and he shows that elasticities will generally be biased down. Using the procedure of Stock and Watson for estimating the low-frequency relationships between variables in small samples, Caballero estimates a long-run elasticity of investment with respect to the user cost of approximately unity. This is much larger than the early estimate, but roughly consistent with the other studies 
summarized in this section.

Euler Equation Estimates. The second approach departs from the strategy of using proxies for marginal $q$, and relies on the firm's Euler equation to model the investment decision. (As long as one makes the same assumption about technology and adjustment costs, the Euler equation can be derived from the same model as the conventional $Q$ or user cost of capital models.) By not relying on the "investment function" representation, one can sidestep problems of measuring marginal $q$.

Tests following this approach have frequently used panel data on manufacturing firms to estimate the Euler equation (Pindyck and Rotemberg, 1983; Shapiro, 1986; Gilchrist, 1991; Whited, 1992; Bond and Meghir, 1994; and Hubbard, Kashyap, and Whited, 1995). Studies using Compustat data for the United States are unable to reject the frictionless neoclassical model for most firms, and the estimated adjustment cost parameters are more reasonable than those found in estimates of $Q$ models. For example, Hubbard, Kashyap, and Whited (1995) report estimated values of $\gamma$ between 1 and 2.2. Very similar estimates are reported for European manufacturing firms by Cummins, Harris, and Hassett (1995) and for investment in overseas subsidiaries of U.S. multinational corporations in Cummins and Hubbard (1995).

Alternatives to $\mathrm{Q}$. The measure of average $Q$ used as a proxy for marginal $q$ in most empirical studies is constructed as the ratio of the market value of the financial claims on the firm (equity and debt) to the replacement cost of the firm's capital stock. The third approach bypasses using financial variables as proxies for marginal $q$ by forecasting the expected present value of the current and future profits generated by an incremental unit of capital - that is, the expected value of marginal $q$ - an idea developed (in the time-series context) by Abel and Blanchard (1986) and 
extended for use in panel data by Gilchrist and Himmelberg (1995). One can extend this setup to a panel-data setting by constructing investment fundamentals using a VAR forecasting framework to decompose the effect of profits or cash flow on investment into two components - one that forecasts future profitability under the frictionless capital markets assumed in the neoclassical model (analogous to marginal $q$ ) and a residual component that may be attributable to financial frictions (analogous to the role played by cash flow in the imperfect-capital-markets approach of Fazzari, Hubbard, and Petersen, 1988a). By including lags of cash flow in the vector of observed fundamentals in the forecasting equations, one can ensure that any information about future marginal profitability of capital contained in cash flow is reflected in the proxy for marginal $q$.

Using such an approach, Gilchrist and Himmelberg (1995) report estimates of $\gamma$ that are roughly consistent with the Euler equation estimates discussed above. In addition, they test whether cash flow is an independent "fundamental" variable explaining investment and find that it is for a subset of firms that are likely to face liquidity constraints. ${ }^{17}$ We return to a discussion of this latter result below.

Measuring Changes in Fundamentals Using Tax Reforms. As we discussed in the previous section, one reason the data do not appear to favor neoclassical models over accelerator models is a simultaneous equations problem: If, on the one hand, the data were dominated by exogenous increases or decreases in the real interest rate, then the user cost movements would lead investment

${ }^{17}$ This is a test of the restricted model against the alternative model that current profits have explanatory power for investment beyond their ability to predict future profits. Gilchrist and Himmelberg find that cash flow is an independent fundamental and that excess sensitivity of investment to cash flow is a characteristic of firms they identify as constrained - measured by size, bond rating, commercial paper rating, or dividend payout. 
to decrease or increase, respectively. If, on the other hand, investment rises with positive "animal spirits," then higher investment demand puts upward pressure on the real interest rate. Hence to the extent that data incorporate both exogenous changes in the real interest rate and in the intercept of the investment function, the positive relationship between investment and the user cost of capital because of shifts in the investment function may dominate the hypothesized negative relationship between investment and the user cost of capital. In this case, the estimated coefficient on the user cost of capital will be "too small," leading to estimated adjustment costs that are "too large." Such simultaneity increases apparent accelerator effects, because positive shifts of the investment function raise both investment and output.

As we noted above, this simultaneity problem in the estimation of neoclassical models is remedied by the use of instrumental variables. Conventional instrumental variables (including lagged endogenous variables or sales-to-capital ratios) have not proven very helpful. Major tax reforms arguably offer periods in which there is exogenous cross-sectional variation in the user cost of capital or tax-adjusted $q$. Cummins, Hassett, and Hubbard $(1994,1996)$ demonstrate that major tax reforms are also associated with significant firm- and asset-level variation in key tax parameters (such as the effective rate of investment tax credit and the present value of depreciation allowances). Hence tax variables are likely to be a good instrument for the user cost or $Q$ during tax reforms.

To indicate the significance of cross-sectional heterogeneity in incentives to invest, we emphasize variation across assets. Figure 5 plots the annual values of $(1-\Gamma)$ for the 22 classes of equipment capital classified by the Bureau of Economic Analysis. The peaks and valleys along the "year" axis for a given asset reveal the time-series variation in the tax parameters, and those along the "asset" axis for a given year reveal the cross-sectional variation. For asset eight (metalworking 
machinery), for example, the after-tax cost of investing falls in 1962, 1972, and 1981, and rises in 1986.

Figure 5 reveals that the variation across assets is large within most years in our samples, as is the time-series variation. In addition, the positions of the peaks and valleys changes somewhat over time. For example, following the removal of the investment tax credit and the reduction of the corporate tax rate by the Tax Reform Act of 1986, the cross-sectional variation across assets fell, consistent with the act's stated goal to "level the playing field."

Cummins, Hassett, and Hubbard (1995) use vector autoregressions to forecast investment in the year following a tax reform, and then compare the forecast errors for each of the assets to the changes in the user cost for that asset. In Figure 6, we repeat that experiment and for the Tax Reform Act of 1986, and provide a plot of the forecast errors constructed from models that exclude taxes against shocks to the user cost of capital for each of the 22 equipment asset classes tracked by the BEA. In addition, we draw a regression line through the scatterplot. The idea is that the forecast errors for investment should be negatively correlated with forecast errors for the user cost of capital. The downward-sloping line indicates a clear negative correlation.

We can now illustrate the effect of tax parameters on firm investment. Table 1 shows the significance of using exogenous tax changes to identify changes in $Q .{ }^{18}$ Taken from Cummins, Hassett, and Hubbard (1996), it presents estimates of the investment equation (14) during major tax reforms in 14 countries over the 1980s; firm-level data are taken from Compustat's Global Vantage. Using contemporaneous tax variables as instrument during major tax reforms, Cummins, Hassett,

${ }^{18}$ Cummins, Hassett, and Hubbard $(1994,1995)$ also use this approach in a user cost model. For U.S. data, they estimate a user cost coefficient of about -0.65 . 
and Hubbard estimate $\gamma$ to be 0.65 for the United States, compared with 0.048 under conventional estimates. They obtained similar estimates for each of the other major U.S. tax reforms in the postwar period using data from Compustat (Cummins, Hassett, and Hubbard, 1994); focusing on the Tax Reform Act of 1986, Auerbach and Hassett (1991) found similar coefficients using asset level data and cross-sectional variation in the user cost. As Table 1 shows, applying the CumminsHassett-Hubbard approach in tax reform periods in other OECD countries produces estimates roughly similar to those for the United States. ${ }^{19}$

Financial Frictions and the Neoclassical Model. In contrast to the frictionless capital markets in the standard neoclassical model, earlier applied research on investment, especially the work of Meyer and Kuh (1957), stressed the significance of financial considerations (particularly internal funds or net worth) for business investment. Since the mid-1960s, however, most applied research on investment isolated "real" firm decisions from "financing." The intellectual justification for this shift in approach drew on the seminal work by Modigliani and Miller (1958), who demonstrated the irrelevance of financial structure and financial policy for real investment decisions

${ }^{19}$ Tax reforms are not the only plausible reform that can be used to estimate adjustment costs. There is a large body of evidence suggesting that union power to expropriate returns is significant, and that the "union tax" adjusts as the return to capital changes. If union wage demands vary with the return to capital, then the union rent share is--in part at least--a tax on capital, distorting the level of investment when it is introduced. Fallick and Hassett (1995) explore whether a change in the union status of the firm is another type of large identifiable shock that affects purchases of capital. Using firm-level panel data, they document a large negative response of investment to union certification elections. For most of the firms who experience union certification elections in their sample, net investment turns significantly negative in the year immediately following the election, with the mean response to union certification being roughly the same size as that which would occur -- given the responsiveness of investment to the user cost in Cummins, Hassett, and Hubbard (1994) -- if the corporate tax rate were increased 35 percentage points. This set of firms, at least, is not burdened by an ability to adjust their capital stock downward when a negative shock to profitability occurs. 
under certain conditions. The central Modigliani-Miller result, which facilitated the early development of the neoclassical model, was that a firm's financial structure will not affect its value in frictionless capital markets. As a result, if their assumptions are satisfied, real firm decisions, motivated by the maximization of shareholders' claims, are independent of financial factors such as the availability of internal funds.

The assumption of representative firms (in terms of trade on capital markets) is common to most research programs in the neoclassical tradition. That is, the same empirical model (e.g., equation (14)) applies to all firms. Therefore, tests could not ascertain whether the observed sensitivity of investment to financial variables differs across firms and whether these differences in sensitivity explain the weak apparent relationship between the measuned user cost and investment. Contemporary empirical studies of information and incentive problems in the investment process have moved beyond the assumption of representative firms by examining firm-level panel data in which firms can be grouped into "high net worth" and "low net worth" categories. For the latter category, changes in net worth or internal funds affect investment, holding constant underlying investment opportunities (desired investment).$^{20}$ Following Fazzari, Hubbard, and Petersen (1988a), empirical researchers have placed firms into groups as a priori "financially constrained" or "financially unconstrained."

Two aspects of the findings of this research program are noteworthy in the context of measuring incentives to invest. First, numerous empirical studies have found that proxies for internal funds have explanatory power for investment, holding constant $Q$, the user cost, or

${ }^{20}$ For reviews of the theoretical literature, see Bernanke, Gertler, and Gilchrist (1996); Hubbard (1990); and Hubbard (1996). 
accelerator variables (see the review of studies in Hubbard, 1995). This suggests that tax policy may have effects on investment by constrained firms beyond those predicted by neoclassical approaches. (Indeed, returning to the "accelerator" analogy, Bernanke, Gertler, and Gilchrist (1996) argue that this literature describes a "financial accelerator.") In particular, the quantity of internal funds available for investment is supported by the average tax on earnings from existing projects. In this sense, average as well as marginal tax rates faced by a firm affect its investment decisions. ${ }^{21}$

Second, empirical studies of financing constraints generally find that the frictionless neoclassical model is rejected only for the groups of firms that a priori are financially constrained (see, e.g., Calomiris and Hubbard, 1995; Gilchrist and Himmelberg, 1995; and Hubbard, Kashyap, and, Whited, 1995). Hence while the shadow value of internal funds may not be well captured for some firms in standard representations of the neoclassical approach, the neoclassical model with convex adjustment costs yields reasonable estimated values of marginal adjustment costs for most firms.

Measurement Error and Adjustment Costs: Nearing Consensus? To summarize, a variety

${ }^{21}$ Fazzari, Hubbard, and Petersen (1988b) and Gertler and Hubbard (1988b) illustrate this point in examining the affect of the investment tax credit on investment. Calomiris and Hubbard (1995) focus on a tax experiment in which retained earnings are taxed more heavily than distributed profits. In frictionless capital markets, firms would take advantage of the incentive to change their payout policies. Working against this response for some firms is the potential difference in the cost of internal and external funds. To the extent that the marginal cost of external funds is high, a growing firm with profitable investment opportunities might choose to pay the undistributed profits tax and invest its internal funds, rather than distribute funds and then reacquire them in the capital market. The U.S. Undistributed Profits Tax of 1936-1937, which imposed a graduated surtax on corporate retention offers a useful experiment. Because the maximum marginal tax rate on corporate retention was 27 percent, most firms had large incentives to alter their payout policies. Using firm-level panel data from the 1930s, Calomiris and Hubbard find that a neoclassical investment model with no explicit capital-market frictions is rejected only for firms with high ex ante surtax margins. 
of empirical implementations of the neoclassical model with convex adjustment costs have attempted to mitigate measurement error and other econometric problems in conventional OLS and GMM estimates of equation (14) in panel data. The methods described above generally yield estimated values of $\gamma$ of 0.50 or higher, implying marginal costs of adjustment in the range of $\$ 0.10$ per dollar

of additional investment (using the estimate in Cummins, Hassett, and Hubbard, 1995 as a benchmark), and elasticities of investment with respect to the user cost of capital between -0.5 and -1.0 .

\section{An Alternative Interpretation: Misspecification of Adjustment Costs}

The emphasis in many recent empirical studies of investment on sources of mismeasurement of explanatory variable acting as proxies for the net return to investing accepts the conventional belief that costs of adjusting the capital stock are convex. The $Q$, user cost of capital, and Euler equation approaches can all be derived from the same intertemporal maximization problem, given common assumptions about technology, competition, and adjustment costs. An important recent line of inquiry focuses on modeling and testing the effects of irreversibility and uncertainty on firms' investment decisions (see, e.g., the excellent survey by Dixit and Pindyck, 1994). ${ }^{22}$ If this literature is correct, then there may be important regions wherein tax policy has little or no effect on investment, and knowledge of which region an economy is currently in is an important prerequisite to any policy analysis. Finally, these models can possibly explain a key remaining puzzle in the

22 The seeds of this literature are much older. For example, Rothschild (1971) writes: "Convex cost-of-adjustment functions may help to explain why Rome was not built in a day. However, there is no clear saving and may be some loss to spreading the work of installing a button on a shirt over several weeks." His "bang-bang" model of investment provides an early example of a "lumpy investment" model. 
literature -- that is, why firms report in surveys that they use such high hurdle rates (see Summers, 1987).

Neoclassical models implicitly assume that there is an efficient secondary market for capital; hence irreversibility poses no problem. If a firm purchases a machine today, and the output market turns sour in the future, the firm can recoup the purchase price of the machine at that time. If, however, investment is irreversible, then the firm faces the chance that it cannot sell the machine in the future. In this setup, there is a gain to delaying investment and allowing the random price process to move either into a region far enough above the neoclassical "breakeven" point that the probability of the "bad state" becomes low enough, or into a region where it clearly does not make sense to purchase the machine. An investment extinguishes the value of the call option of delay, an option that has positive value when prices are uncertain. In this approach, the value of the lost option is a component of the opportunity cost of investment. In the terminology of the $Q$ framework, the threshold criterion for investment requires that marginal $Q$ exceed unity by the value of maintaining the call option to invest. As a consequence, high "hurdle rates" may be required by corporate managers making investment decisions.

Indeed, at least part of the interest in option-based investment models has been the problem raised in many time-series studies that indicated that the response of investment to changes in $Q$ or the user cost of capital are implausibly small, implying, perhaps, that there are regions wherein $Q$ varies but investment does not. In addition, it is not difficult to suggest examples of nonconvex adjustment costs—-such as retooling in automobile plants or the adoption of more energy-efficient kilns in cement plants.

How Much Investment Is Irreversible? Before turning to models with alternative adjustment 
cost specifications, we present in this subsection a prima facie case that pure irreversibility may not be of overriding importance at the aggregate level.

There is a large literature (see, e.g., Hulten and Wykoff, 1979; Jorgenson, 1994; Fraumeni, 1995; and Oliner, 1996) that focuses on the estimation of economic depreciation rates for different types of machines. For the most part, researchers estimate rates of decay from the patterns of used machine prices. This literature is relevant to the debate concerning the form of adjustment costs because irreversibility results most plausibly from either the absence of resale markets, or from the presence of significant "lemons" problems in resale markets.

To examine the extent to which resale markets are limited, we surveyed the depreciation literature and catalogued types of equipment for which we could find an estimated economic depreciation rate. Using disaggregated data on investment by asset type, we than calculated the proportion of aggregate investment that is made up of assets that have clearly identifiable resale markets. Figure 4 plots this proportion from 1950 to 1994. The proportion of investment in assets that have easily identifiable resale markets is about 0.7 over most of the period. This is not to say that the remaining assets are necessarily "irreversible," of course; depreciation studies may not yet have found data for those assets.

Hence in order to demonstrate that irreversibility is an important property of most investment goods, researchers must show that the market for used capital goods is plagued with lemons problems. To our knowledge, there is no existing evidence that lemons are important in markets for equipment goods. Indeed, Hulten and Wykoff (1981) argue that estimated secondary market prices in depreciation studies are inconsistent with a major role for lemons problems. One reason for this finding may be that the market for used capital goods is one where the participants possess 
significant asset-specific expertise. The typical purchaser of a machine tool, for example, may have worked in a factory filled with machine tools for many years, and would easily recognize a "lemon." If this is the case, there is little asymmetric information, and the resale market functions well.

Models with More General Adjustment Costs. Abel and Eberly (1994) provide a general framework that encompasses irreversibility, fixed costs, and a wide array of alternative adjustment cost specifications. They show that, under certain conditions, the investment behavior of firms can be characterized by three distinct regimes: (1) regime in which gross investment is positive; (2) regime in which gross investment is zero; (3) regime in which gross investment is negative. The responsiveness of investment to fundamentals differs across regimes, and their more general model predicts that there is a region in which gross investment will stay zero for a range of unfavorable values of $Q$. Because this model nests the more traditional $q$ models, it provides a useful empirical framework, and we review attempts to estimate this model below.

Researchers are beginning to study the impact of alternative adjustment cost assumptions within structural investment models with panel data. Barnett and Sakellaris (1995) use Compustat data to investigate the implication of the model of Abel and Eberly (1995) that investment alternates between regimes of insensitivity to $Q$ and regimes of responsiveness to $Q$. The region of inactivity should be close to the region for which the model predicts that investment is negative. Because the thresholds for these regions are unknown, conventional asymptotic distributions do not apply. Barnett and Sakellaris use a statistical framework that allows them to estimate the threshold points and the coefficients on $Q$ simultaneously in the different regions given the threshold points. They find evidence of a nonlinear relationship between investment and $Q$; in particular, they estimate the largest responsiveness of investment to $Q$ for low values of $Q$, and the smallest for very high values 
of $Q$. On average, they estimate that the elasticity of investment with respect to $Q$ is about unity, but that the aggregate elasticity varies considerably over time, depending on the average level of $Q$. Barnett and Sakellaris argue that their results imply that adjustment cost may not be quadratic, but that the most likely cause is not firms' inability to disinvest, but rather, their reluctance to make "large" changes.

Barnett and Sakellaris's results are not necessarily inconsistent with the measurement error story. Some firms in their Compustat universe have values of average $Q$ that are astronomical (one firm actually has a $q$ of 40,000 !), presumably because the capital stock measure is missing important goodwill or human capital components. If one accepts that $Q$ is a poor measure of fundamentals for these firms, then the result that investment does not respond as much to $Q$ for these firms is not surprising. In the more "normal" range of $Q$ values, the investment response seems to accord well with the predictions of the convex adjustment cost model.

Finally, Caballero, Engel, and Haltiwanger (1995) explore adjustment costs in a more general framework. Using a subset of 7000 U.S. manufacturing plants from the Census Bureau's Longitudinal Research Database (LRD), they explore whether cross-sectional patterns of investment are consistent with symmetric, convex adjustment cost models, or whether the data imply that there are nonconvexities. ${ }^{23}$ They proceed in two steps. First, they assume that there are no adjustment costs and that the Jorgensonian model adequately describes a firms "desired" capital stock $\left(K^{*}\right) .{ }^{24}$

${ }^{23}$ In earlier work, Doms and Dunne (1994) report that plant-level investment data exhibit skewness and kurtosis that is consistent with investment being somewhat "lumpy."

24 To calculate the desired capital stock for each firm, Caballero, Engel, and Haltiwanger use plant-level output data, and two-digit Jorgensonian user costs constructed from the tax data used in Cummins, Hassett, and Hubbard (1994) and Goolsbee (1995). 
They then compare in each period a firm's beginning-of-period capital stock to its desired stock and call the difference $\left(K^{*}-K_{t-l}\right)$ "mandated investment." Second, they explore how firms actually adjust their capital stocks. In this step, they find that the relationship between actual and mandated investment is highly nonlinear. If mandated investment is negative, then firms do not quickly adjust their capital stocks downward. If mandated investment is small and positive, then firms also do not respond very much. If mandated investment is very large, then firms adjust their capital stocks very quickly. They conclude that an $(S, s)$ model, in which firms have a range of inaction, and only adjust their capital stocks to their desired levels when the gap between current and desired capital stock is "large enough" offers a good description of the data.

Using firm-level data from Compustat, Abel and Eberly (1996) estimate that the relationship between investment and fundamental determinants ( $Q$ and the tax-adjusted price of capital goods) is concave; that is, the response of investment to fundamental determinants is positive, but monotonically declining. The results of Abel and Eberly suggest that the distribution of tax-adjusted $Q$ or the user cost of capital may be a determinant of aggregate investment. However, the caution that applied to Barnett and Sakellaris conclusions applies here as well: Large observed values of $Q$ may not coincide with high levels of investment because the high $Q$ values reflect mismeasurement, rather than extraordinary fundamentals.

Caballero, Engel, and Haltiwanger also illustrate how to construct aggregate implications from their microeconomic results. Integrating over the microeconomic distribution of plants, they calculate a predicted aggregate elasticity of investment with respect to the user cost of capital. The estimates of this elasticity vary considerably over time: If, on the one hand, many plants are near the region for which mandated investment is very large, then small changes in the user cost can have 
large effects on aggregate investment. If, on the other hand, the bulk of the distribution of mandated investment is in the region of low responsiveness of investment to fundamentals, then changes in the user cost will have little impact. They concur with the main conclusion of Cummins, Hassett, and Hubbard (1994) that the aggregate elasticity of investment with respect to the user cost is between -0.5 and -1 , and also conclude that tax reforms appear to have generally had large effects on investment. They caution, however, that the reforms have had large effects because they coincidentally occurred during periods in which the plant-level distribution of mandated investment was aligned in such a way to allow a large effect of changes in tax parameters. This would happen if, for example, investment tax credits were removed in booms, when mandated investment is very large, and an increase in the user cost can cause firms to cancel significant investment plans. As a consequence, Caballero, Engel, and Haltiwanger argue that researchers must consult the micro distribution of mandated investment before predicting the likely impact of future tax reforms on business investment. ${ }^{25}$

Alternatively, Cummins, Hassett, and Hubbard $(1994,1996)$ argue that recovering "reasonable" estimates of the response of investment to $Q$ or the user cost of capital is easiest during periods in which large exogenous changes in the distribution of structural determinants occur, as during tax reforms. In response to the alternative interpretation that firms respond only to changes in fundamentals when these changes are large, Cummins, Hassett, and Hubbard use firm-level data

25 Because their mandated investment measure is the same as that in a frictionless neoclassical model, their tests -- while suggestive -- neither confirm or reject the presence of convex adjustment costs. First, mandated investment itself depends on adjustment costs. Second, if adjustment costs were present, mandated investment also depends on future values of tax parameters 
to investigate whether there was evidence of "bunching" of investment around tax reforms. They estimate transition probabilities among various ranges of $(I / K)$ over the year prior to, of, and after the tax reform, and find no evidence that firms with large investment were likely to have lower investment in prior or subsequent years. Indeed, only a very tiny fraction of the sample was ever found to transit from high investment to low investment states.

In part, the conclusions of these studies may differ because of differences in the level of aggregation. At a sufficiently fine level of disaggregation, all investment looks lumpy. The plantlevel evidence suggests that investment appears lumpy, but the firm-level evidence does not corroborate this. However, there may be interesting differences between the investment behavior of plants and firms, as might be the case if, for example, managerial attention is limited and only a fraction of a firm's plants adjust their capital in a given year. Clearly, reconciling the plant-level and firm-level results is an important topic for future research.

\section{Summing Up: The Partial Equilibrium Effects of Investment Tax Policy}

Recent studies appear to have reached a consensus that the elasticity of investment with respect to the user cost of capital is between -0.5 and -1.0 . Indeed, recent studies using convex costs of adjustment and studies using nonconvex costs of adjustments agree that the long-run elasticity of investment to the user cost is high by the standards of the early empirical literature. This range of estimated responses of investment to tax parameters is well above the consensus of only a few years ago, and suggests that investment tax policy can have a significant impact on the path of aggregate capital formation. One should be cautious, however, in moving from the microeconomic evidence to aggregate predictions. Caballero, Engel, and Haltiwanger demonstrate a technique for aggregating the micro distribution of firms to calculate aggregate investment demand, but very little 
continues to be known about the general equilibrium effects of major policy changes.

\section{Arguments For and Against Investment Incentives}

Thus far we have argued that: (1) tax incentives for investment are important components of the net return to investing, and (2) the short-term and long-term responses of investment to permanent tax incentives are large. We now turn to the deeper policy question of whether we should have permanent incentives for investment even if such incentives increase the stock of business fixed capital. (We then address the question of the desirability of short-run incentives.) Economists generally argue against intervention. Under what circumstances might one advocate distortionary investment incentives?

\section{A. Do Investment Incentives Affect the Price of Capital Goods?}

One scenario under which investment incentives might have an especially large impact on the quantity of investment without dissipation in prices of investment goods is one in which firms' demand for capital is responsive to changes in the user cost of capital and in which capital goods are supplied perfectly elastically. While it is implausible that the supply function for most individual capital goods manufacturers is perfectly elastic, the effective supply of capital goods to a given domestic market might well be highly elastic in the long run if the world market for capital goods is open. Investment incentives would raise prices of capital goods in the short run if the supply of capital goods is highly inelastic.

Using data for the United States and ten other countries, Hassett and Hubbard (1995) find that local investment tax credits have a negligible effect on prices paid for capital goods, indeed, they find that the capital goods prices for most countries are very highly correlated, and that the movements of these over time are consistent with "the law of one price." In addition, using 
disaggregated data on asset-specific investment good prices and tax variables for the United States, they find that tax parameters have no effect on capital goods prices. ${ }^{26}$ The conclusion that tax policy in the United States does not affect the world price of capital goods is especially meaningful, given the relative size of the U.S. economy. Taken together, these tests suggest that the effects of investment tax policy have not been muted in a significant way by upward-sloping supply schedules for capital goods.

\section{B. Is the Capital Stock Too Small?}

While it is instructive to ask how effective investment incentives are at increasing the fixed capital stock, a more important question remains: What is the social value of the increase in the fixed capital stock?

Theoretical research has demonstrated that perfectly competitive economies do not necessarily converge to the "correct" capital stock. Indeed, Diamond (1965) demonstrated that a competitive economy can reach a steady state in which there is "too much" capital, in the sense that the economy is investing more than it is earning in profit. In this case, individuals can be made better off if they are forced to consume a portion of the capital stock. When evaluating investment incentives, it is crucial for policy analysis to evaluate whether the economy is operating with "too much" or "too little" capital.

\footnotetext{
${ }^{26}$ Goolsbee (1995) argues that U.S. tax shocks are positively correlated with capital price movements. The difference in the two sets of results arises from two sources. First, Goolsbee uses the ITC as a measure of the tax change, rather than the full user cost of capital. Second, Goolsbee's price regressions relate the level of the price to the level of the ITC, while Hassett and Hubbard use the first-difference of the price (because the price series used are highly nonstationary). When the model is estimated in levels, the uncorrected regression errors contain unit roots.
} 
The classic "golden rule" literature offers benchmarks for guidance. ${ }^{27}$ In the golden rule approach of Phelps (1961), the golden rule level of the capital stock relative to output is achieved when the marginal product of capital $(R)$ net of depreciation ( $\delta$ ) equals the sum of the rate of growth of the labor force $(n)$ and the rate of labor-augmenting technical change $(g)$, or:

$$
R=\delta+n+g .
$$

Alternatively, in the optimal growth literature, Ramsey (1928) golden rule levels require that the marginal product of capital net of depreciation equal the sum of the social rate of time preference ( $\rho$ ) and the elasticity of marginal social utility with respect to per capita consumption $(\Phi)$ or $^{28}$

$$
R=\delta+\rho+\phi g .
$$

Depending on the values of $\rho$ and $\phi$, the Ramsey golden-rule levels of capital can be less than the Phelps golden-rule levels.

Following the conventional in neoclassical models of the capital stock, we assume a CobbDouglas technology, so that the ratio of the steady-state golden-rule capital stock $\left(K^{*}\right)$ to output $(Y)$ equals the ratio of capital's share in output $(\alpha)$ to the marginal product of capital $(R)$. Moreover, the golden rule level of net investment $(I)$ relative to output equals $(n+g)$ times the capital-output ratio.

27 Another argument for subsidies to equipment investment has been advanced by Judd (1995), who concludes that the optimal tax on equipment investment is negative. He argues that, to the extent that capital-goods-producing industries are imperfectly competitive (owing, say, to the presence of patents), equipment prices contain significant markups. Hence to return firms' input mix to the optimal level, the government should design an investment subsidy that equates the price paid for equipment to its marginal cost.

${ }^{28}$ See, e.g., the analysis in Blanchard and Fischer (1989). 
Hence:

$$
\frac{K^{*}}{Y}=\frac{\alpha}{R},
$$

and

$$
\frac{I^{*}}{Y}=(n+g) \frac{K^{*}}{Y} .
$$

One can account for different types of capital by noting that, in equilibrium, the net rates of return on the alternative types are equal. Hence one can substitute into (17) measures of $\alpha_{k}$ for each type of capital $k$ and the relevant $R$ (given differences in depreciation), and solve for the golden rule levels of the capital stocks.

Using a range of parameter values in the golden rule expressions in (17) and (18), Cohen, Hassett, and Kennedy (1995) compare golden rule and actual levels of the capital stock or net investment relative to output to their actual values over the period from 1980-1994. Table 2, which we excerpt from several tables in that study indicates that for benchmark parameter values, equipment investment and capital stocks are below their golden rule levels (assuming 1980-1994 is sufficiently long to characterize a steady state), while residential investment and the residential capital stocks -- which have received significant tax subsidies over this time period -- are near or above their golden rule levels. Cohen, Hassett, and Kennedy also show that these conclusions are not changes if the key parameters are allowed to vary across a broad range of plausible values. 
Alternatively, several authors have attempted to evaluate the optimality of the U.S. capital stock by relating various interest rates to the rate of economic growth. One the one hand, Tobin (1965), Solow (1970), and Feldstein (1977) argue that the marginal productivity of capital one obtains from accounting profits estimates is about 10 percent, and thus conclude that the economy is dynamically efficient. On the other hand, Ibbotson (1987) calculates a mean return on U.S. Treasury bills from 1926-1986 of only 0.3 percent, suggesting dynamic inefficiency. The answer to the question using interest rates depends critically on assessing the impact of risk, of course.

Abel, Mankiw, Summers, and Zeckhauser (1989) pursue an alternative strategy for evaluating whether the U.S. capital stock is greater or less than the optimal level. In a stochastic setting with a very general production technology, they demonstrate that an economy is dynamically inefficient if it invests more than the returns from capital. They show that the economy is dynamically efficient -- and hence in the range in which stimulative tax policy might have positive social returns -- if the returns from capital exceed investment. Using their terminology, the key question is whether the capital stock is on balance a "sink" or a "spout." This observation is a useful contribution because it allows one to base judgment about dynamic efficiency on readily observable cash flows. Abel, et al. conclude that the economy is dynamically efficient. Thus, both capital stock data and "cash flow" data suggest that, by raising the stock of equipment capital, investment

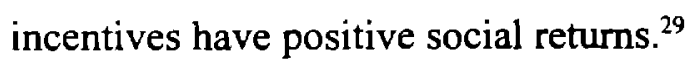

\section{Should We Use Temporary Investment Incentives?}

The discussion thus far pertains to permanent changes in investment incentives. Even a

${ }^{29}$ Because the golden rule models are developed for a closed economy, it is difficult to extend the comparison to domestic versus foreign fixed capital. 
casual observation of the history of investment incentives since the 1950s suggests the usefulness of considering temporary investment incentives. Since 1962, the mean duration of a typical state in which an ITC is in effect has been about three and one-half years, and the mean duration of the "no-ITC" state has been about the same length. Most recently, President Bush advocated a modified ITC, known as the "Investment Tax Allowance" in 1992, and President Clinton proposed an incremental ITC in early 1993; neither of these measures was enacted. What is the likely impact on aggregate capital accumulation of temporary investment incentives?

Temporary investment incentives can have even larger short-run impacts on investment than permanent investment incentives (see, e.g., Auerbach, 1989). Consider, for example, a temporary ITC known to last for one period. The expression for the user cost of capital in equation (5) indicates that the ITC lowers the current user cost both through its effect on $\Gamma_{i, t}$ and through the consequences of its removal on $\Gamma_{i, l+1}$. More generally, anticipated future changes in tax policy affect the current value of the user cost and investment.

The large potential effects of temporary tax incentives on investment do not imply that they are desirable tax policy -- even if one believes that long-run investment incentives are sound tax policy. In the presence of uncertainty and adjustment costs, there is little reason to believe that policymakers can "time" investment incentives for the purposes of stabilization policy. Moreover, the use of temporary incentives increases uncertainty in business capital budgeting, making it more difficult for firms to forecast the path of the user cost of capital.

\section{Does Uncertainty About Tax Policy Affect Investment?}

What if firms do not know the exact timing of changes in investment incentives -- that is, if tax policy is uncertain? There is a substantial literature evaluating the effects of price uncertainty 
on investment, and the lesson from this literature is that the sign of the effect of uncertainty on investment depends crucially on assumptions about adjustment costs and returns to scale. Hartman (1972) shows that uncertainty generally increases investment in a model with constant returns and convex adjustment costs. Abel (1983) derives a similar result in continuous time. Pindyck (1988), however, shows that uncertainty can significantly lower capital formation if investment is irreversible and if retums to scale are decreasing. We described Pindyck's intuition earlier: In an uncertain world, there is a gain to delaying investment -- the option value of waiting -- and these gains are higher the higher is the variance in the output price.

Thus, one might be tempted to conclude from the early contributions to this literature that the predicted effect of tax policy uncertainty will depend on what we believe about the reversibility -- or lack thereof -- of capital investments. However, strictly speaking, tax policy uncertainty can even increase investment in the models of Hartman, Abel, and Pindyck (see Hassett and Metcalf, 1994, 1995).

This difference arises because tax policy uncertainty is unlike price uncertainty in an important way. Researchers often introduced uncertainty by assuming that the price follows a continuous-time random walk (Brownian motion or geometric Brownian motion). When prices follow a random walk, the appropriate rational expectations forecast for the price at any time in the future is today's price, and the future path of the price is unbounded. Unlike most prices, tax parameters tend to remain constant for a few years, and then jump to new values. In addition, jumps in the ITC tend to be mean-reverting: When the credit is high, it is likely to be reduced in the future; when the credit is low, it is likely to be increased in the future. Because of these properties, the normal gain to waiting in a model with irreversibility is reduced significantly when an investment 
tax credit is "on": Because the firm fears that the credit might be eliminated, it is more likely to invest today while the credit is still effective. Hassett and Metcalf demonstrate that this effect dominates the reverse effect in the state in which there is no investment tax credit, and conclude that increasing tax policy uncertainty raises aggregate investment.

As with the case of temporary investment incentives generally, this result does not imply that random tax policy is desirable. Most existing studies analyze investment in a partial equilibrium setting wherein there are no utility costs to bunching capital formation. In a general equilibrium setting, Bizer and Judd (1989) show that welfare is reduced significantly by random investment tax policy. The randomness has a negative impact because consumers wish to smooth consumption, and fluctuations in investment credits make smoothing costly.

\section{Policy Implications}

Our finding of significant short-term and long-term effects of the user cost of capital on equipment investment suggests applications to current policy debates. In particular, we evaluate in this section consequences for the user cost and investment of a reduction in inflation and a switch from an income tax to a broad-based consumption tax.

\section{A. Low Inflation as a "Costless" Investment Subsidy}

Many economists (see, e.g., Feldstein, 1976; and King and Fullerton, 1984) have argued that under fairly general assumptions, a reduction in the rate of inflation provides a relatively costless

stimulus to business fixed investment by reducing the user cost of capital. Returning to the expression for the user cost, there are two channels through which expected inflation affects investment decisions. First, for given values of $r$ and $\delta$, the user cost varies positively with the level of expected inflation $\pi$ because the present value of depreciation allowances - which is formed 
using the nominal rate, $r+\pi$, as a discount rate - varies inversely with inflation owing to historical-cost depreciation. ${ }^{30}$ Second, inflation affects the real cost of funds, $r$. In this section, we briefly illustrate this second channel (following Auerbach, 1983b), and calculate the extent to which lower inflation over the past decade had led to a reduction in the user cost of capital.

In a small open economy, the real cost of debt would be determined in world capital markets, and would be exogenously given to firms. If the capital market were closed, then the marginal tax rate of the holder of debt would affect the interest rates that firms pay. That is, local debtholders require a fixed real after-tax return, $r$, where:

$$
r=i\left(1-\tau_{p}\right)-\pi
$$

where $i$ is the nominal interest rate on corporate debt, $\tau_{p}$ is the marginal personal tax rate on interest income, and $\pi$ is the expected rate of inflation. The inflation premium component of interest income is taxable to bondholders. The firm's real cost of debt, $\rho_{d}$, depends on its own marginal income tax rate, $\tau_{\mathrm{c} \text { : }}$

$$
\rho_{d}=i\left(1-\tau_{c}\right)-\pi
$$

because under current U.S. tax law nominal interest payments on corporate debt are fully deductible. Combining the two previous expressions relates the firms real cost of debt to the investor's required

${ }^{30}$ That is, the present value of depreciation allowances is given by:

$$
\sum_{s=1}^{\infty}\left(1+r_{s}+\pi_{s}\right) \tau_{s} D E P_{i s}(s-t)
$$

where $D E P(a)$ is the depreciation allowance permitted an asset of age $a$, discounted at a nominal rate that includes the expected inflation rate $\pi$. 
return and marginal tax rate:

$$
\rho_{d}=(r+\pi) \frac{\left(1-\tau_{c}\right)}{\left(1-\tau_{p}\right)}-\pi
$$

Alternatively,

$$
\rho_{d}=\frac{r\left(1-\tau_{c}\right)+\left(\tau_{p}-\tau_{c}\right) \pi}{\left(1-\tau_{p}\right)}
$$

The firm's real cost of equity finance, $\rho_{e}$, is defined as:

$$
\rho_{e}=D+E-\pi, \quad i
$$

where $D$ is the dividend-price ratio and $E$ is investors' required ex-dividend nominal return to equity.

Note that, for a given $r$, inflation has very little effect on the cost of debt finance if -- as is likely the case in the United States -- $\tau_{c}$ is approximately equal to $\tau_{p}$. In this case, lower inflation reduces the nominal interest deduction but lowers the tax liability of bondholders by the same amount. Note also that the effects of inflation on the cost of debt finance depend crucially on the assumption that the marginal debt holder is taxable. If the marginal debtholder is a pension fund (whose income is not taxed under current law), then lower inflation unambiguously increases the cost of debt finance. Firms receive smaller interest deductions, and pension funds do not accrue an offsetting reduction in tax liability. ${ }^{31}$

${ }^{3 \prime}$ There is no clear consensus regarding the effects of marginal tax rates on domestic real interest rates, or on the question of whether the "Fisher effect" implicit in equation (21) holds. This is an important area for future research in this context. 
Individuals receive the after-tax real return:

$$
\rho_{i}=\left(1-\tau_{i}\right) D+(1-c) E-\pi
$$

where $\tau_{\mathrm{i}}$ is the individual's marginal tax rate on dividend income, and $c$ is the individual's accrual equivalent tax rate on capital gains. Combining terms, the firm's real cost of equity finance is:

$$
\rho_{e}=\frac{\left(\tau_{i}-c\right)}{(1-c)} D+\frac{\rho_{i}}{(1-c)}+\frac{c}{(1-c)} \pi
$$

Higher inflation unambiguously increases the cost of equity finance by the factor $c /(1-c)$. This term captures the "inflation tax" paid by shareholders who receive purely nominal gains; taxation of real capital gains would eliminate this effect. ${ }^{32}$

The total real cost of investment funds is simply the weighted average of the cost of equity and the cost of debt, where the weights are the share of each in marginal finance. Using this approach, one can examine the effect on investment of recent declines in expected inflation. Cohen, Hassett, and Hubbard (1996) calculate the marginal effects on the user cost of lowering inflation. ${ }^{33}$

\footnotetext{
${ }^{32}$ For the calculations described below, we do not include the first term reflecting the tax on dividends. In effect, we adopt the "tax capitalization" view of equity taxation (summarized in Auerbach, 1983b) which suggests that the relevant tax rate is the effective capital gains tax rate, regardless of the amount of dividends paid. This view assumes that marginal equity funds come primarily from retained earnings rather than from new share issues and that earnings distributions to shareholders are primarily through dividends rather than share repurchases.

33 Earlier empirical studies of the effect of inflation on real business tax burdens include Feldstein and Summers (1977) and Auerbach (1983 b). Cohen, Hassett, and Hubbard (1996) also allow for inflation to increase taxes paid because of the effects of inflation on the cost of carrying inventories.
} 
They estimate that, under plausible assumptions, the current value of the user cost for equipment investment is about 0.22 , and they conclude that a one-percentage-point permanent decrease in inflation lowers the user cost by about one-half a percentage point. In their calculations, the incremental effect of each additional percentage point reduction in inflation is approximately the same. Thus if the annual inflation rate were reduced from four percent to zero, the user cost of capital would decline about two percentage points -- proportionally by about ten percent. Given the elasticity estimates reviewed in the previous section, this "tax cut" would provide a significant stimulus to investment.

\section{B. Moving to a Consumption Tax}

Under the income tax, the user cost of capital is influenced by the corporate tax rate, investment tax credits, and the present value of depreciation allowances (see equation (4)). Under a broad-based consumption tax, firms pay tax on the difference between receipts and purchases from other firms. That is, there is no investment tax credit, and investment is expensed $(z=1)$. In this case (assuming that the corporate tax rate does not change over time), the user cost of capital simplifies to:

$$
c_{i, t}=p_{1}\left[r_{t}+\delta-\frac{\Delta p_{t+1}}{p_{l}}\right] .
$$

Comparing the user cost expressions in (4) and (4') leads to two observations. First, under a consumption tax, taxes do not distort business investment decisions; investment decisions are based on nontax fundamentals. Second, given current U.S. tax policy, the user cost is lower under a consumption tax than under an income tax. 
By how much? Under current law, and assuming that the output price and the capital goods price are both equal to unity, then for assets with seven-year lives, (assuming that the expected real interest rate is four percent, the expected inflation rate is three percent, and the marginal machine is financed half with equity and half with debt), the value of $(1-\Gamma) /(1-\tau)$ under 1996 U.S. tax law is 1.148 , and the user cost of capital is equal to 0.234 . The move to the consumption tax would lower the value of the user cost to 0.205 , a reduction that would lead, ceteris paribus, to about a 10 percent increase in equipment investment given the consensus estimates of $\gamma$ in equation (14).

Of course, other aggregate variables are also likely to change in response to such a large change to the tax code were adopted. For example, nominal interest rates and the supply of savings are likely to change. While it is difficult to say how large, the net stimulus to investment would be, the consensus of the recent investment literature suggests that the partial equilibrium impact on investment may be quite large.

\section{Conclusions}

Economists and policymakers have long been concerned about the effects of business taxation and investment incentives on the equilibrium capital stock and the timing of investment. Such concerns figure prominently in research programs: (1) identifying impacts of tax parameters on fundamental determinants of investment; (2) describing links between fundamentals and the capital stock or investment; and (3) testing models of those links. Studies within the neoclassical tradition offer rigorous applications of (1) and (2), but, until recently, have not produced reasonable empirical estimates of effects of fundamental on investment. Indeed, the poor empirical performance of neoclassical factors led some researchers to conclude that "taxes don't matter" and still others to question assumptions of the neoclassical paradigm. 
Our principal conclusions are four. First, neoclassical models that use convex costs of adjusting the capital stock to derive investment equations yield economically important short-run and long-run effects of tax policy on investment. This result reflects recent research which, through a number of complementary approaches, demonstrates that measurement error in fundamentals biases downward conventional estimates of tax effects. Second, at least for data on firm-level investment, predictions of models with nonconvex adjustment costs are no more coṇsistent with observed links between fundamentals and investment than those of models with convex adjustment costs. Third, recent studies conclude that U.S. business investment is below its "golden rule" level. Finally, consensus estimates of the impact of the user cost of capital on investment indicate that two current policy suggestions -- pursuing a monetary policy that would reduce expected inflation and switching from an income tax to a consumption tax -- would significantly stimulate investment.

The current state of research on business investment decisions suggests the desirability of developing tests to distinguish among alternative models of costs of adjusting the capital stock. Different adjustment cost specifications imply different time paths of the response of the capital stock to tax policy, making such tests useful for policymakers. Nonetheless, most recent studies imply a high long-run elasticity of the capital stock to the user cost of capital, so that tax policy clearly has the potential to have a powerful effect on equipment investment and the capital stock in the long run. 


\section{REFERENCES}

Abel, Andrew B. (1990). "Consumption and Investment." In Benjamin M. Friedman and Frank H. Hahn, eds., Handbook of Monetary Economics, Volume 2. Amsterdam: North-Holland.

Abel, Andrew B. (1983). "Optimal Investment Under Uncertainty." American Economic Review 73 (March): 228-233.

Abel, Andrew B. (1980). "Empirical Investment Equations: An Integrative Framework." Journal of Monetary Economics 12 (Spring), 39-91.

Abel, Andrew B., and Olivier J. Blanchard. (1986). "The Present Value of Profits and Cyclical Movements in Investment." Econometrica 54 (March), 249-273.

Abel, Andrew B., and Janice C. Eberly. (1995). "The Effects of Irreversibility and Uncertainty on Capital Accumulation." Working Paper No. 5363, National Bureau of Economic Research, November.

Abel, Andrew B., and Janice C. Eberly. (1996). "Investment and $q$ with Fixed Costs: An Empirical Analysis." Mimeograph, The Wharton School, January.

Abel, Andrew B., and Janice C. Eberly. (1995). "Optimal Investment with Costly Irreversibility." Working Paper No. 5091, National Bureau of Economic Research, April.

Abel, Andrew B., and Janice C. Eberly. (1994). "A Unified Model of Investment Under Uncertainty." American Economic Review 84 (September), 1369-1384.

Abel, Andrew B., N. Gregory Mankiw, Lawrence H. Summers, and Richard J. Zeckhauser. (1989). "Assessing Dynamic Efficiency: Theory and Evidence." Review of Economic Studies 56, $1-20$.

Aftalian, A. (1909). "La reálité des surproductions générales, essui d'une théorie des crises générales et periodiques." Revue d'Economie Politique.

Auerbach, Alan J. (1983a). "Corporate Taxation in the United States." Brookings Papers on Economic Activity 2, 451-513.

Auerbach, Alan J. (1989). "Tax Reform and Adjustment Costs: The Impact on Investment and Market Value." International Economic Review 30, 939-962.

Auerbach, Alan J. (1983b). "Taxation, Corporate Financial Policy, and the Cost of Capital." Journal of Economic Literature 21 (September), 905-940. 
Auerbach, Alan J., and Kevin A. Hassett. (1991). "Recent U.S. Investment Behavior and the Tax Reform Act of 1986: A Disaggregate View." Carnegie-Rochester Conference Series on Public Policy 35 (Autumn), 185-215.

Auerbach, Alan J., and Kevin A. Hassett. (1992). "Tax Policy and Business Fixed Investment in the United States." Journal of Public Economics 47, 141-170.

Auerbach, Alan J., Kevin A. Hassett, and Jan Södersten. (1995). "Taxation and Corporate Investment: The Impact of the 1991 Swedish Tax Reform." Working Paper No. 5189, National Bureau of Economic Research, July.

Barnett, Steven A., and Plutarchos Sakellaris. (1995). "Nonlinear Response of Firm Investment to $Q$ : Testing a Model of Convex and Nonconvex Adjustment Costs." University of Maryland Working Paper No. 95-11, October.

Bernanke, Ben, Henning Bohn, and Peter C. Reiss. (1988). "Alternative Nonnested Specification Tests of Time-Series Investment Models." Journal of Econometrics 37 (March): 293-326.

Bernanke, Ben, Mark Gertler, and Simon Gilchrist. (1996). "The Financial Accelerator and the Flight to Quality." Review of Economics and Statistics, forthcoming.

Bischoff, Charles. (1971). "Business Investment in the 1970s: A Comparison of Models." Brookings Papers on Economic Activity 1: 13-63.

Bizer, David, and Kenneth Judd. (1989). "Taxation and Uncertainty." American Economic Review 79 (May), 331-336.

Blanchard, Olivier Jean, and Stanley Fischer. (1989). Lectures on Macroeconomics. Cambridge: MIT Press.

Blundell, Richard, et al. (1992). "Investment and Tobin's Q." Journal of Econometrics 57, 233257.

Bond, Stephen, and Costas Meghir. (1994). "Dynamic Investment Models and the Firm's Financial Policy." Review of Economic Studies 61: 197-222.

Bosworth, Barry P. (1985). "Taxes and the Investment Recovery." Brookings Papers on Economic Activity 1, 1-38.

Braudel, Fernand. (1992). The Wheels of Commerce. Berkeley: University of California Press.

Cabellero, Ricardo J. "Small Sample Bias and Adjustment Costs." (1994). Review of Economics and Statistics, 52-58. 
Caballero, Ricardo J., and John V. Leahy. (1995). "Fixed Costs: The Demise of Marginal q." Mimeograph, MIT, December.

Caballero, Richard J., Eduardo M. R. A. Engel, and John C. Haltinwanger. (1995). "Plant-level Adjustment and Aggregate Investment Dynamics." Brookings Papers on Economic Activity $2,1-54$

Calomiris, Charles W., and R. Glenn Hubbard. (1995). "Internal Finance and Investment: Evidence from the Undistributed Profits Tax of 1937-1938." Journal of Business 68 (October), 443482 .

Chirinko, Robert S. (1993). "Business Fixed Investment Spending: Modeling Strategies, Empirical Results, and Policy Implications." Journal of Economic Literature 31 (December), 18751911.

Chirinko, Robert S. (1987). "The Ineffectiveness of Effective Tax Rates on Business Investment: A Critique of Feldstein's Fisher-Schultz Lecture." Journal of Public Economics 32, 369-387.

Chirinko, Robert S., and Robert Eisner. (1983). "Tax Policy and in Major Macroeconomic Models." Journal of Public Economics 20, 139-166.

Clark, J.M. "Business Acceleration and the Law of Demand. (1917). " Journal of Political Economy 25 (March), 217-235.

Clark, Peter K. (1993). "Tax Incentives and Equipment Investment." Brookings Papers on Economic Activity 1, 317-339.

Cochrane, John. (1991). "Production-Based Asset Pricing and the Link Between Stock Returns and Economic Fluctuations." Journal of Finance 46 (March): 209-237.

Cohen, Darrel, Kevin A. Hassett, and R. Glenn Hubbard. (1996). "Inflation and the User Cost of Capital: Does Inflation Still Matter?" Mimeograph, Columbia University, December.

Cohen, Darrel, Kevin A. Hassett, and James Kennedy. (1995). "Are U.S. Investment and Capital Stocks at Their Optimal Levels?" FEDS Working Paper No. 9532, Board of Governors of the Federal Reserve System.

Cummins, Jason G. Kevin A. Hassett, and R. Glenn Hubbard. (1995). "Have Tax Reforms Affected Investment?" In James M. Poterba, ed. Tax Policy and the Economy, vol. 9. Cambridge: MIT Press.

Cummins, Jason G., Kevin A. Hassett, and R. Glenn Hubbard. (1994). "A Reconsideration of Investment Behavior Using Tax Reforms as Natural Experiments." Brookings Papers on Economic Activity2, 1-74. 
Cummins, Jason G., Trevor S. Harris, and Kevin A. Hassett. (1995). "Accounting Standards, Information Flow, and Firm Investment Behavior." In Martin Feldstein, James R. Hines, and R. Glenn Hubbard, eds., The Effects of Taxation on Multinational Corporations. Chicago: University of Chicago Press.

Cummins, Jason G., Kevin A. Hassett, and R. Glenn Hubbard. (1996). "Tax Reforms and Investment: A Cross-Country Comparison." Journal of Public Economics, forthcoming.

Cummins, Jason G., and R. Glenn Hubbard. (1995). "The Tax Sensitivity of Foreign Direct Investment: Evidence from Firm-Level Panel Data." In Martin Feldstein, James R. Hines, and R. Glenn Hubbard, eds., The Effects of Taxation on Multinational Corporations. Chicago: University of Chicago Press.

Diamond, Peter A. (1965). "National Debt in a Neoclassical Growth Model." American Economic Review 55 (December): 1126-1150.

Dixit, Avinash K., and Robert S. Pindyck. (1994). Investment Under Uncertainty. Princeton: Princeton University Press.

Doms, Mark, and Timothy Dunne. (1994). "Capital Adjustment Patterns in Manufacturing Plants." Discussion Paper 94-11. Washington, D.C.: Center for Economic Studies, U.S. Bureau of the Census.

Eisner, Robert. (1969). "Tax Policy and Investment Behavior: Comment." American Economic Review 59 (June), 379-388.

Eisner, Robert. (1970). "Tax Policy and Investment Behavior: Further Comment." American Economic Review 60 (September), 746-752.

Eisner, Robert and M. Ishaq Nadiri. (1968). "Investment Behavior and Neoclassical Theory." Review of Economics and Statistics 50: 369-382.

Eisner, Robert and M. Ishaq Nadiri. (1970). "Neoclassical Theory of Investment Behavior: A Comment." Review of Economics and Statistics 52 (May): 216-222.

Eisner, Robert, and Robert H. Strotz. (1963). "Determinants of Business Investment." In Impacts of Monetary Policy, studies prepared for the Commission on Money and Credit. Englewood Cliffs, N.J.: Prentice-Hall.

Fallick, Bruce C., and Kevin A. Hassett. (1995). "Union Certification and Investment," Mimeograph, Board of Governors of the Federal Reserve System, September.

Fazzari, Steven M., R. Glenn Hubbard, and Bruce C. Petersen. (1988a). "Financing Constraints and Corporate Investment." Brookings Papers on Economic Activity 1, 141-195. 
Fazzari, Steven M., R. Glenn Hubbard, and Bruce C. Petersen. (1988b). "Investment, Financing Decisions, and Tax Policy." American Economic Review 78 (May), 200-205.

Feldstein, Martin S. (1977). "Does the United States Save Too Little?" American Economic Review 67 (May): 116-121.

Feldstein, Martin S. and Lawrence H. Summers. (1979). "Inflation and the Taxation of Capital Income in the Corporate Sector." National Tax Journal 32 (December): 445-470.

Feldstein, Martin S. (1976). "Inflation, Income Taxes, and the Rate of Interest: A Theoretical Analysis." American Economic Review 66 (June): 8809-820.

Feldstein, Martin S. (1982). "Inflation, Tax Rules, and Investment: Some Econometric Evidence." Econometrica 50 (July), 825-862.

Fisher, Irving. The Theory of Interest. (1930). New York: Macmillan.

Fraumeni, Barbara M. (1995). "The Measurement of Depreciation in the U.S. National Income and Wealth Accounts." Mimeograph, National Science Foundatiop, January.

Gertler, Mark, and R. Glenn Hubbard. (1988). "Financial Factors in Business Fluctuations." In Financial Market Volatility: Causes and Consequences. Kansas City: Federal Reserve Bank of Kansas City.

Gilchrist, Simon. (1991). "An Empirical Analysis of Corporate Investment and Financing Hierarchies Using Firm-Level Panel Data." Mimeograph, Board of Governors of the Federal Reserve System.

Gilchrist, Simon, and Charles P. Himmelberg. (1995). "Evidence on the Role of Cash Flow in Reduced-Form Investment Equations." Journal of Monetary Economics 36: 541-572.

Goolsbee, Austan. (1995). "Investment Tax Incentives and the Price of Capital Goods." Mimeograph, University of Chicago.

Gould, John P. (1968). "Adjustment Costs in the Theory of Investment of the Firm." Review of Economic Studies 35, 47-55.

Griliches, Zvi, and Jerry A. Hausman. (1986). "Errors in Variables in Panel Data." Journal of Econometrics 31 (February, 141-154.

Haavelmo, Trygve. A Study in the Theory of Investment. (1960). Chicago: University of Chicago Press.

Hall, Robert E., and Dale W. Jorgenson. (1967). "Tax Policy and Investment Behavior." American Economic Review 57 (June), 391-414. 
Hartman, Richard. (1972) "The Effects of Price and Cost Uncertainty on Investment." Journal of Economic Theory 5: 258-266.

Hassett, Kevin A., and R. Glenn Hubbard. (1995). "The World Market for Capital Goods: Does Local Policy Affect Prices?" Mimeograph, Columbia University, December.

Hassett, Kevin A., and Gilbert E. Metcalf. (1994). "Investment with Uncertain Tax Policy: Does Random Tax Policy Discourage Investment?" Working Paper No. 4780, National Bureau of Economic Research, June.

Hassett, Kevin A., and Gilbert E. Metcalf. (1995). "Random Taxes and Continuous Investment." Working Paper, Tufts University.

Hayashi, Fumio. (1985). "Corporate Finance Side of the $Q$ Theory of Investment." Journal of Public Economics 27, 261-280.

Hayashi, Fumio. (1982). "Tobin's Marginal $q$ and Average $q$ : A Neoclassical Interpretation." Econometrica 50 (January), 213-224.

Hayashi, Fumio, and Tohru Inoue. (1991). "The Relation Between Firm Growth and $q$ with Multiple Capital Goods: Theory and Evidence from Panel Data on Japanese Firms."Econometrica 59 (May), 731-753.

Himmelberg, Charles P. (1991). "A Dynamic Analysis of Dividend and Investment Behavior Under Borrowing Constraints." Mimeograph, New York University.

Hubbard, R. Glenn. (1995). "Capital-Market Imperfections and Investment." Mimeograph, Columbia University, December.

Hubbard, R. Glenn. (1990). "Introduction." In R. Glenn Hubbard, ed. Asymmetric Information, Corporate Finance, and Investment. Chicago: University of Chicago Press.

Hubbard, R. Glenn. (1994). "Investment Under Uncertainty: Keeping One's Options Open." Journal of Economic Literature 32 (December), 1816-1831.

Hubbard, R. Glenn, and Anil K. Kashyap. (1992). "Internal Net Worth and the Investment Process: An Application to U.S. Agriculture." Journal of Political Economy 100 (June), 506-534.

Hubbard, R. Glenn, Anil K. Kashyap, and Toni M. Whited. (1995). "Internal Finance and Firm Investment." Journal of Money, Credit, and Banking 27 (August), 683-701.

Hulten, Charles R., and Frank C. Wykoff. (1981). "The Measurement of Economic Depreciation." In Charles R. Hulten, ed., Depreciation, Inflation, and the Taxation of Income from Capital. Washington, D.C.: Urban Institute. 
Hulten, Charles R., and Frank C. Wykoff. (1979). "Tax and Economic Depreciation of Machinery and Equipment: A Theoretical and Empirical Appraisal." Working Paper, U.S. Treasury Department, Office of Tax Analysis, July.

Ibbotson, R.G. (1987). Stocks, Bonds, Bills, and Inflation: Market Results for 1926-1986. Ibbotson and Associates.

Jorgenson, Dale W. (1963). "Capital Theory and Investment Behavior." American Economic Review 53 (May), 247-259.

Jorgenson, Dale W. (1971). "Econometric Studies of Investment Behavior: A Survey." Journal of Economic Literature 9 (December), 1111-1147.

Jorgenson, Dale W. (1967). "Theory of Investment Behavior." In Robert Ferber, ed., "Determinants of Investment Behavior." New York: Columbia University Press.

Jorgenson, Dale W., and Calvin D. Siebert. (1968). "A Comparison of Alternative Theories of Corporate Investment Behavior." American Economic Review 58 (September), 681-712.

Jorgenson, Dale W., and Stephenson. (1969). "Issues in the Devetopment of the Neoclassical Model." Review of Economics and Statistics 51 : 346-353.

Jorgenson, Dale W., and Martin A. Sullivan. (1981). "Inflation and Corporate Capital Recovery." In Charles R. Hulten, ed., Depreciation, Inflation, and the Taxation of Income from Capital. Washington, D.C.: Urban Institute.

Jorgenson, Dale W. (1994). "Empirical Studies of Depreciation." Working Paper, Harvard Institute of Economic Research No. 1704, December.

Judd, Kenneth L. (1995). “The Optimal Tax Rate for Capital Income Is Negative.” Working Paper, Hoover Institution, April 1995.

Keynes, John Maynard. (1936). The General Theory of Employment, Interest, and Money. New York: Harcourt Brace.

King, Mervyn A., and Don Fullerton, eds. (1984). The Taxation of Income from Capital: $A$ Comparative Study of the United States, United Kingdom, Sweden, and West Germany. Chicago: University of Chicago Press.

Lucas, Robert E., Jr. (1967). "Adjustment Costs and the Theory of Supply." Journal of Political Economy 75 (August), 321-334.

Lucas, Robert E., Jr. (1976). "Econometric Policy Evaluation: A Critique." In Karl Brunner and Allan Meltzer, eds., The Phillips Curve and Labor Markets, Carnegie-Rochester Conference Series on Public Policy 1: 19-46. 
Meyer, John R., and Edwin Kuh. (1957). The Investment Decision. Cambridge: Harvard University Press.

Modigliani, Franco, and Merton H. Miller. (1958). "The Cost of Capital, Corporation FInance and the Theory of Investment." American Economic Review 48 (June ), 261-297.

Mortenson, Dale T. (1973). "Generalized Costs of Adjustment and Dynamic Factor Demand Theory." Econometrica 41: 657-667.

Nickell, Stephen J. (1978). The Investment Decisions of Firms. Cambridge: Cambridge University Press.

Oliner, Stephen D. (1996). "New Evidence on the Retirement and Depreciation of Machine Tools." Economic Inquiry, forthcoming.

Phelps, Edmund S. (1961). "The Golden Rule of Accumulation: A Fable for Growth Men." American Economic Review 51: 638-643.

Pindyck, Robert S. (1988). "Irreversible Investment, Capacity Choice, and the Value of the Firm." American Economic Review 78 (December): 969-985.

Pindyck, Robert S. (1991). "Irreversibility, Uncertainty, and Investment." Journal of Economic Literature 29 (September): 1110-1148.

Pindyck, Robert S., and Julio J. Rotemberg. (1983). "Dynamic Factor Demands Under Rational Expectations." Scandinavian Journal of Economics 85: 223-238.

Ramsey, Frank P. (1928). "A Mathematical Theory of Saving." Economic Journal 62: 543-559.

Rothschild, Michael. (1971). "On the Costs of Adjusting the Capital Stock." Quarterly Journal of Economics 85, 6056-22.

Sakellaris, Plutarchos. (1996). "Investment Under Uncertain Market Conditions." Review of Economics and Statistics, forthcoming.

Salinger, Michael A., and Lawrence H. Summers. (1983). "Tax Reform and Corporate Investment: A Microeconomic Simulation Study." In Martin Feldstein, ed., Behavioral Simulation Methods in Tax Policy Analysis. Chicago: University of Chicago Press.

Shapiro, Matthew D. (1986). "The Dynamic Demand for Capital and Labor." Quarterly Journal of Economics 101 (August): 513-547.

Sinn, Hans-Werner. (1987). Capital Income Taxation as Resource Allocation. Amsterdam: North-Holland. 
Södersten, Jan. (1989). "The Investment Funds System Reconsidered." Scandinavian Journal of Economics 91 (December), 671-87

Solow, Robert. (1970). Growth Theory. Oxford: Oxford University Press.

Stock, James H., and Mark W. Watson. (1993). "A Simple MLE of Cointegrating Vectors in Higher Order Integrated Systems." Econometrica 61 (January): 111-152.

Struckmeyer, Charles S. (1983). "Capital, Energy, and Economic Growth: A Vintage Approach." Doctoral Dissertation, Yale University.

Summers, Lawrence H. (1987). "Investment Incentives and the Discounting of Depreciation Allowances." In Martin Feldstein, ed., The Effects of Taxation on Capital Accumulaiton. Chicago: University of Chicago Press.

Summers, Lawrence H. (1981). "Taxation and Corporate Investment: A $q$-Theory Approach." Brookings Papers on Economic Activity 1, 67-127.

Taylor, John B. (1993). Macroeconomic Policy Design in a World Economy: From Econometric Design to Practical Operation. New York: W.W. Norton.

Taylor, John B. (1982). "The Swedish Investment Funds System as a Stabilization Policy Rule." Brookings Papers on Economic Activity 1, 57-101.

Tobin, James. (1965). "Economic Growth as an Objective of Government Policy." In Essays in Economics, Volume 1: Macroeconomics. Amsterdam: North-Holland.

Tobin, James. (1969). "A General Equilibrium Approach to Monetary Theory." Journal of Money, Credit, and Banking 1 (February), 15-29.

Treadway, A. B. (1970). "Adjustment Cost and Variable Imports in the Theory of the Competitive Firm." Journal of Economic Theory 2, 329-347.

Treadway, A. B. (1969). "On Rational Entrepreneurial Behavior and the Demand for Investment." Review of Economic Studies 36, 227-239.

Uzawa, H. (1969). "Time Preference and the Penrose Effect in a Two-Class Model of Economic Growth." Journal of Political Economy 77: 628-652.

Whited, Toni M. (1992). "Debt, Liquidity Constraints, and Corporate Investment." Journal of Finance 47 (September), 1425-1460. 
TABLE 1

Estimates of Tax-Adjusted $Q$ Model for Fourteen Countries"

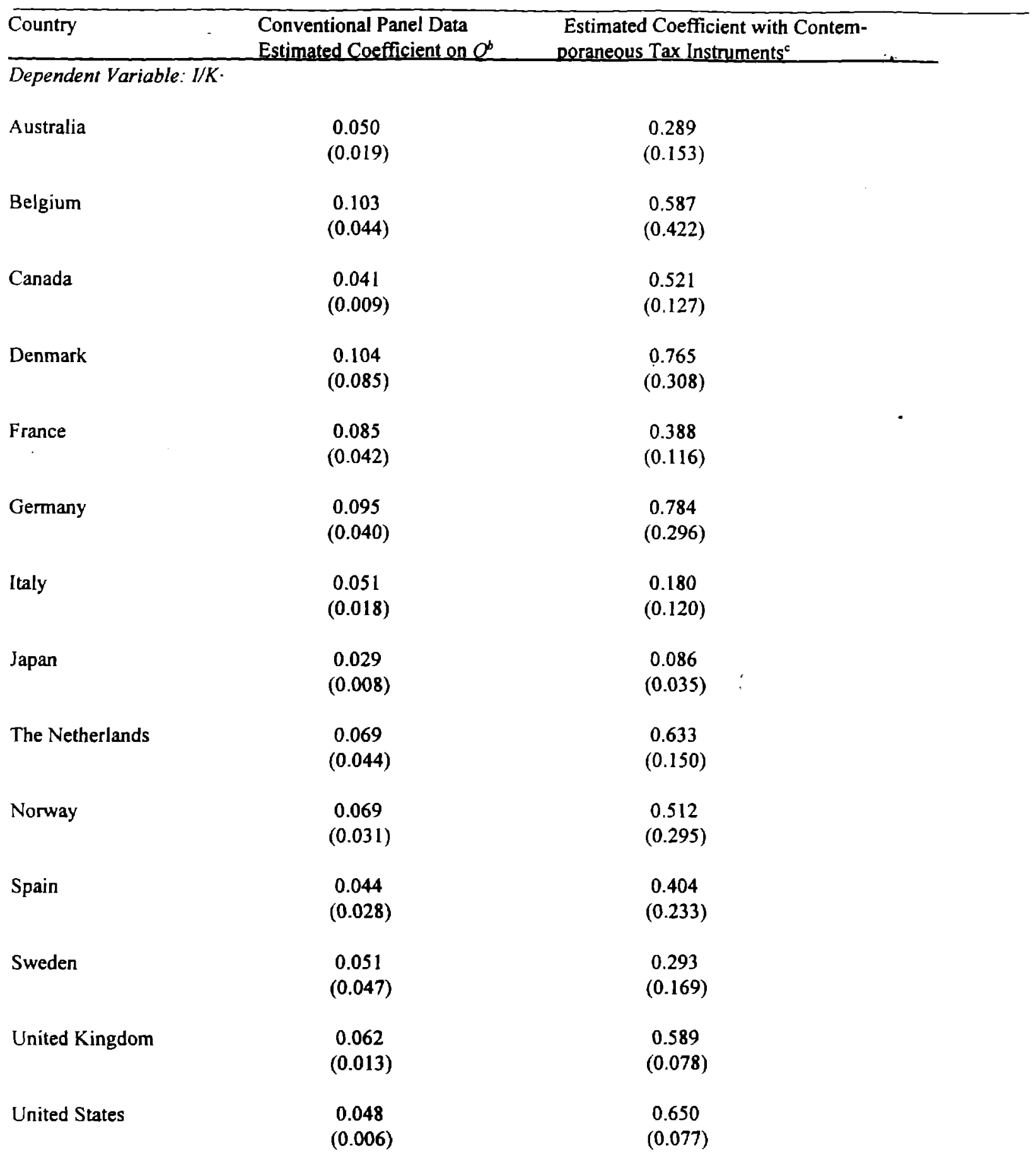

Notes: ' Source: Calculations in Cummins, Hassett, and Hubbard (1996) using Global Vantage data.

b See Table 5 in Cummins, Hasseth, and Hubbard (1996), GMM estimates. Instruments include twice- and thrice-lagged values of $Q,(1 / K)$, and the ratios of cash flow to capital.

c See Table 7 in Cummins, Hassett, and Hubbard (1996), GMM estimates. Instruments include twice- and thrice-lagged values of $(I / K)$ and the ratio of cash flow to capital, twice-lagged value nontax components of $q$, and contemporaneous values of tax parameters. 


\section{TABLE 2}

Benchmark Golden-Rule and Actual Levels of $\mu^{\text {eet }} / Y$ and $K / Y$

Type of Capital

Golden-Rule Level

Phelps Ramsey
Actual Level

(1980-1994 average)

Net Investment as Percent of GDP:

Total fixed

Business fixed

Producers durable

equipment

Nonresidential structures

Residential
$8.3 \%$

4.8

2.4

2.0

2.7
$6.0 \%$ $4.2 \%$

3.6

2.4

1.3

1.2

1.8

$1.6 \quad 1.8$

Ratio of Capital Stock to GDP:

Total fixed

Business fixed

Producers durable

equipment

Nonresidential structures

Residential
3.3

1.9

2.4

1.9

1.4

1.0

Source: Cohen, Hassett, and Kennedy (1995, Table 2).

Note: Benchmark parameter values are:

Labor force growth rate $=0.01$

Rate of labor-augmenting technical change $=0.15$

Social discount rate $=0.12$

Social intertemporal elasticity of substitution $(\Phi)=3$

$\alpha_{\text {Total fixed }}=0.30, \alpha_{\text {Business fixed }}=0.24, \alpha_{\text {Equipment }}=0.18, \alpha_{\text {Structures }}=0.06, \alpha_{\text {Residential }}=0.06$ 


\section{Fundamental Determinants of Equipment Spending}

User Cost of Capital

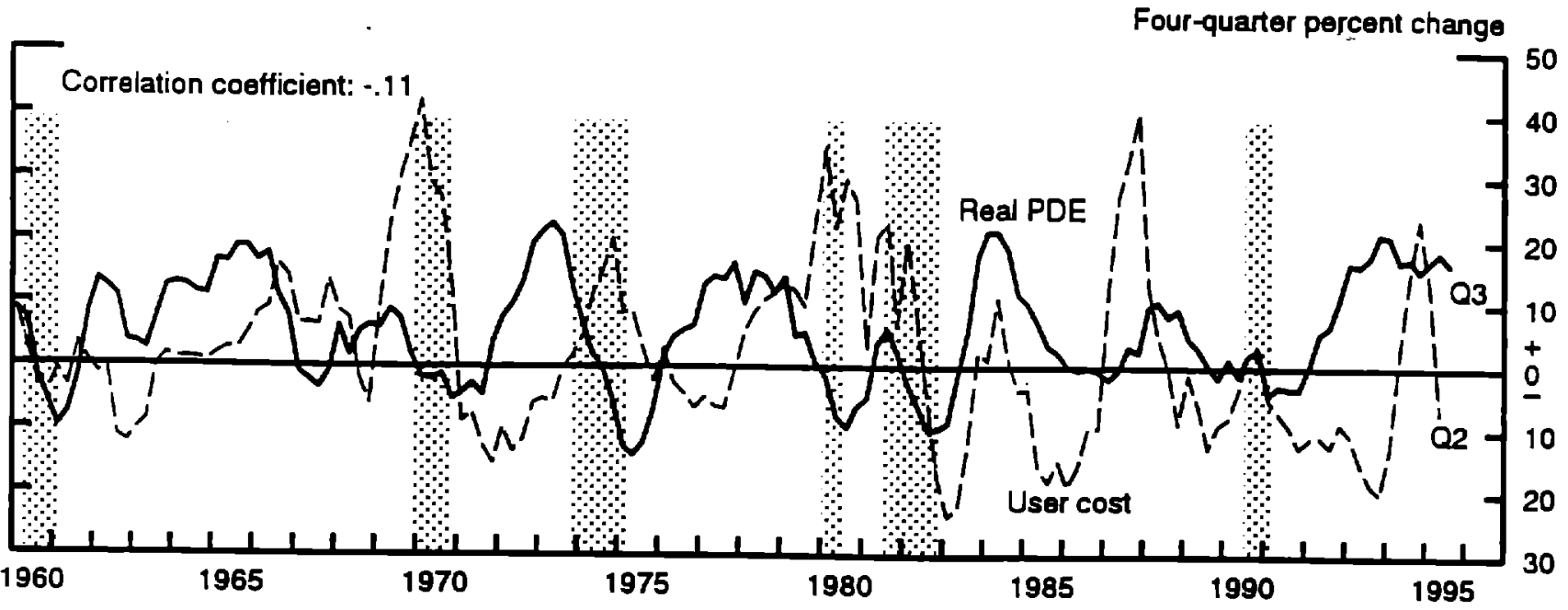

Real Domestic Corporate Cash Flow
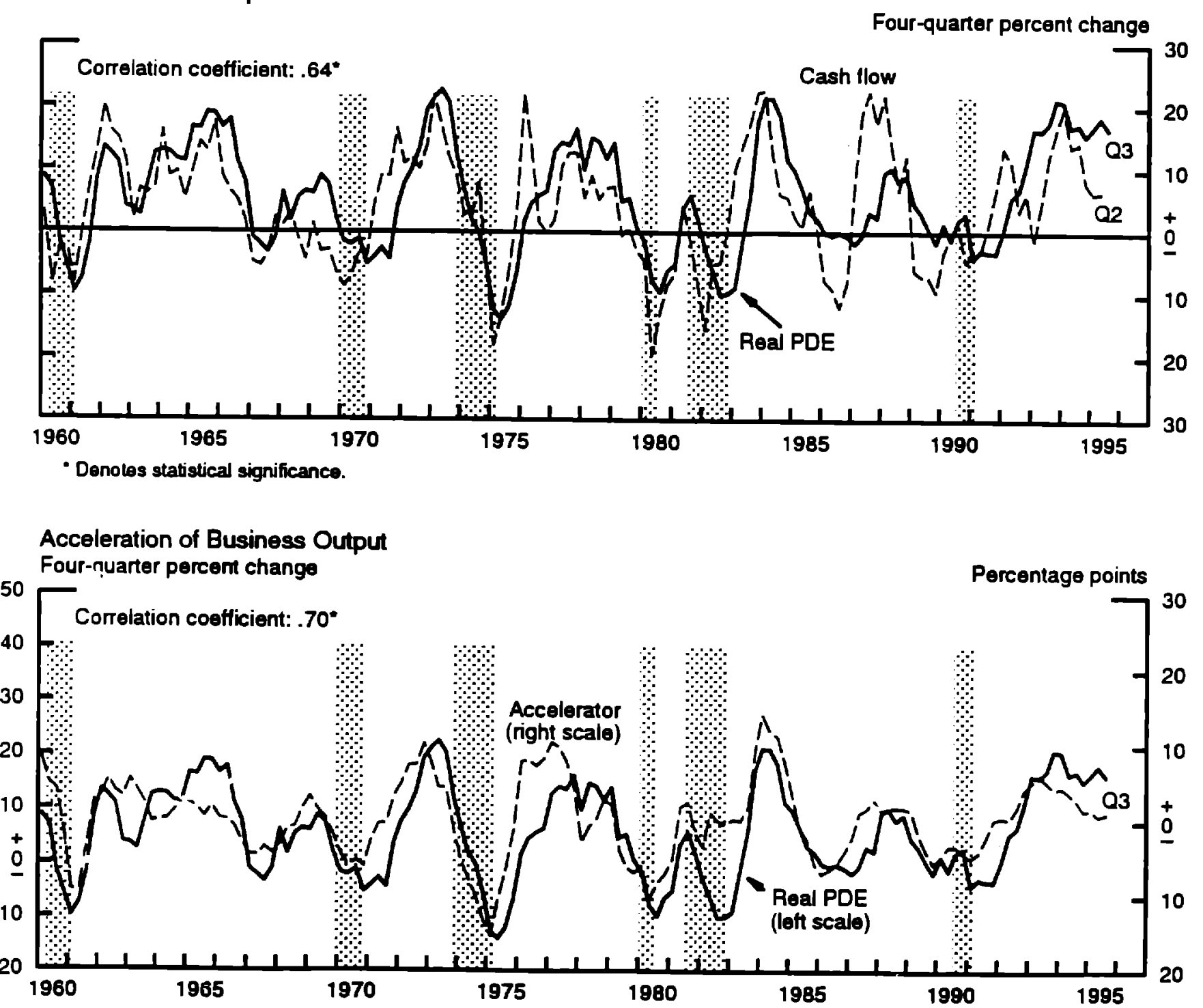

Note. The accelerator is the eight-quartor percent change in business output less the year-eartier eight-quarter percent change. 


\section{Fundamental Determinants of NRS Spending}

NRS Cost of Capital

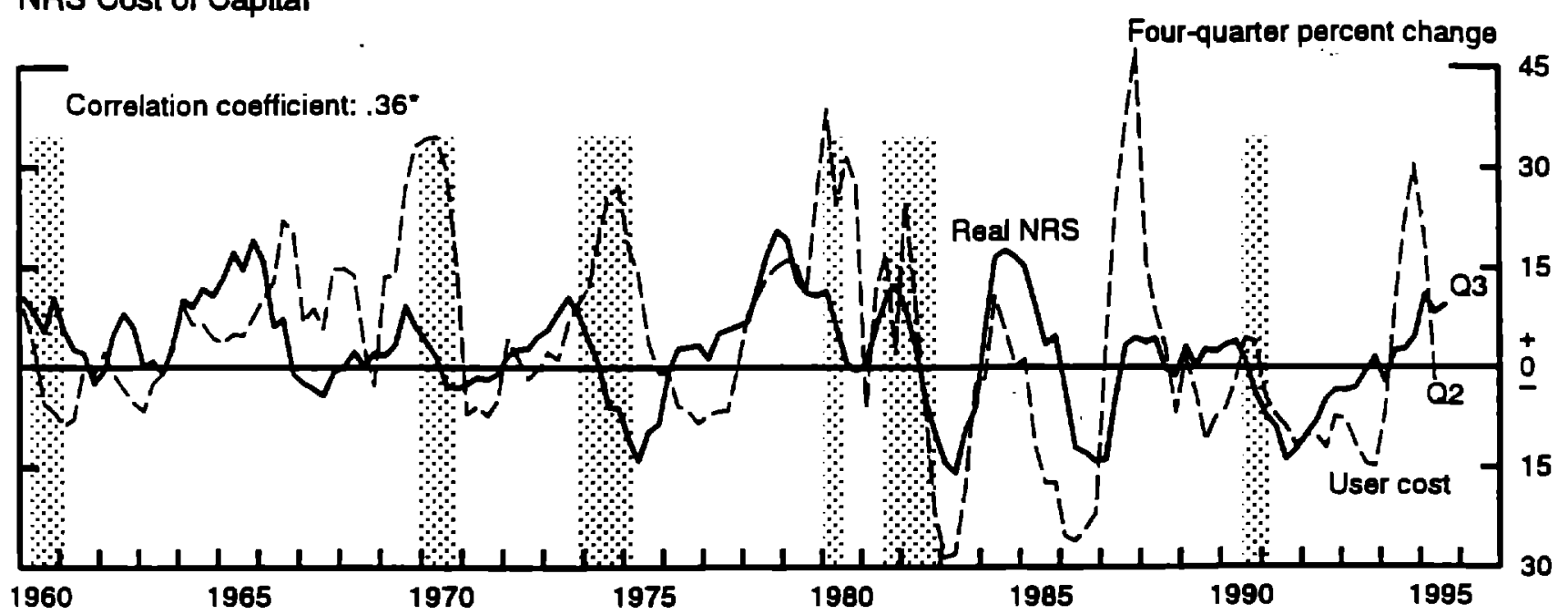

- Denotes statistical significance.

Real Domestic Corporate Cash Flow
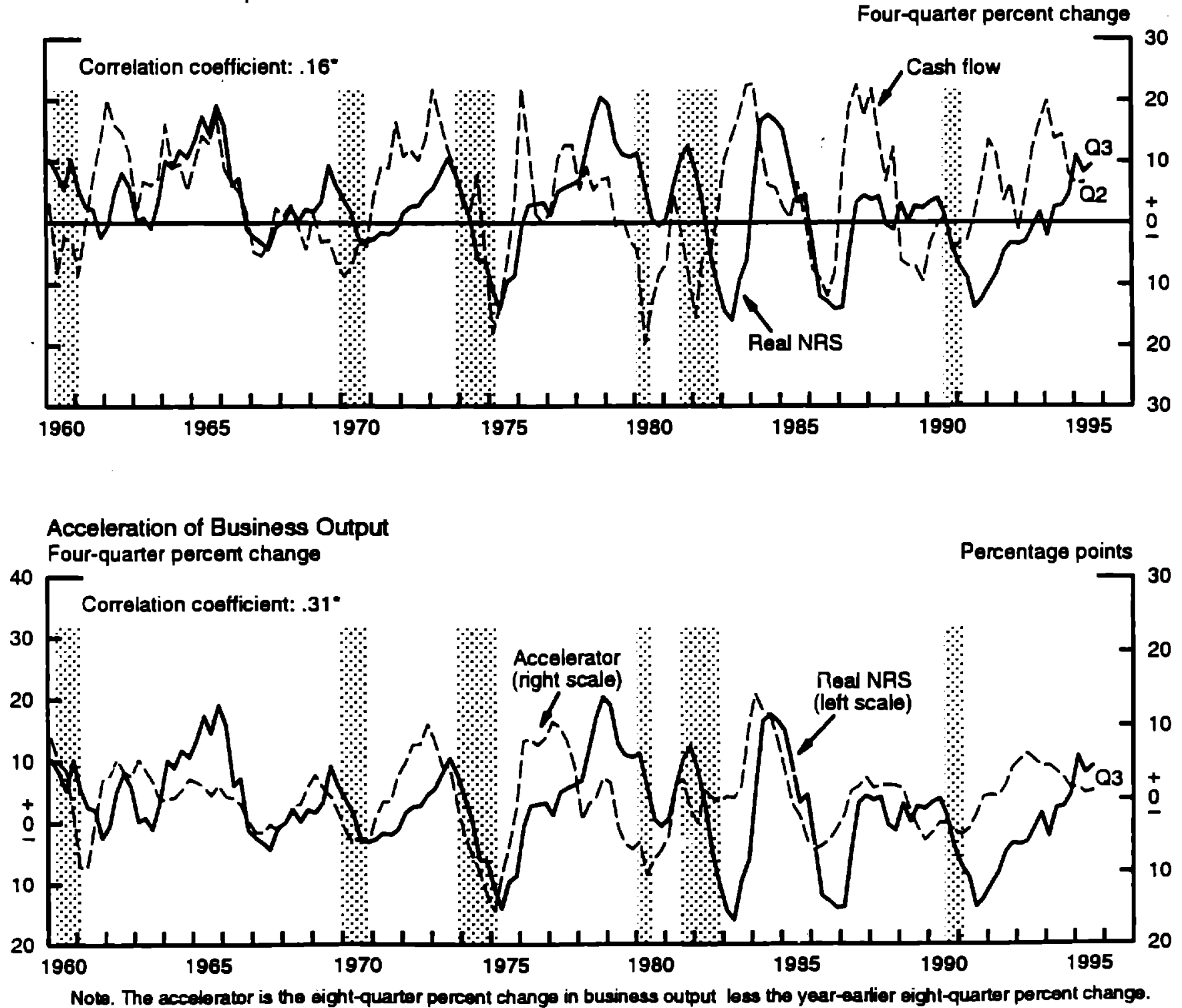
Figure 3

\section{Tobin's $\mathbf{Q}$ and the V/K Ratio}
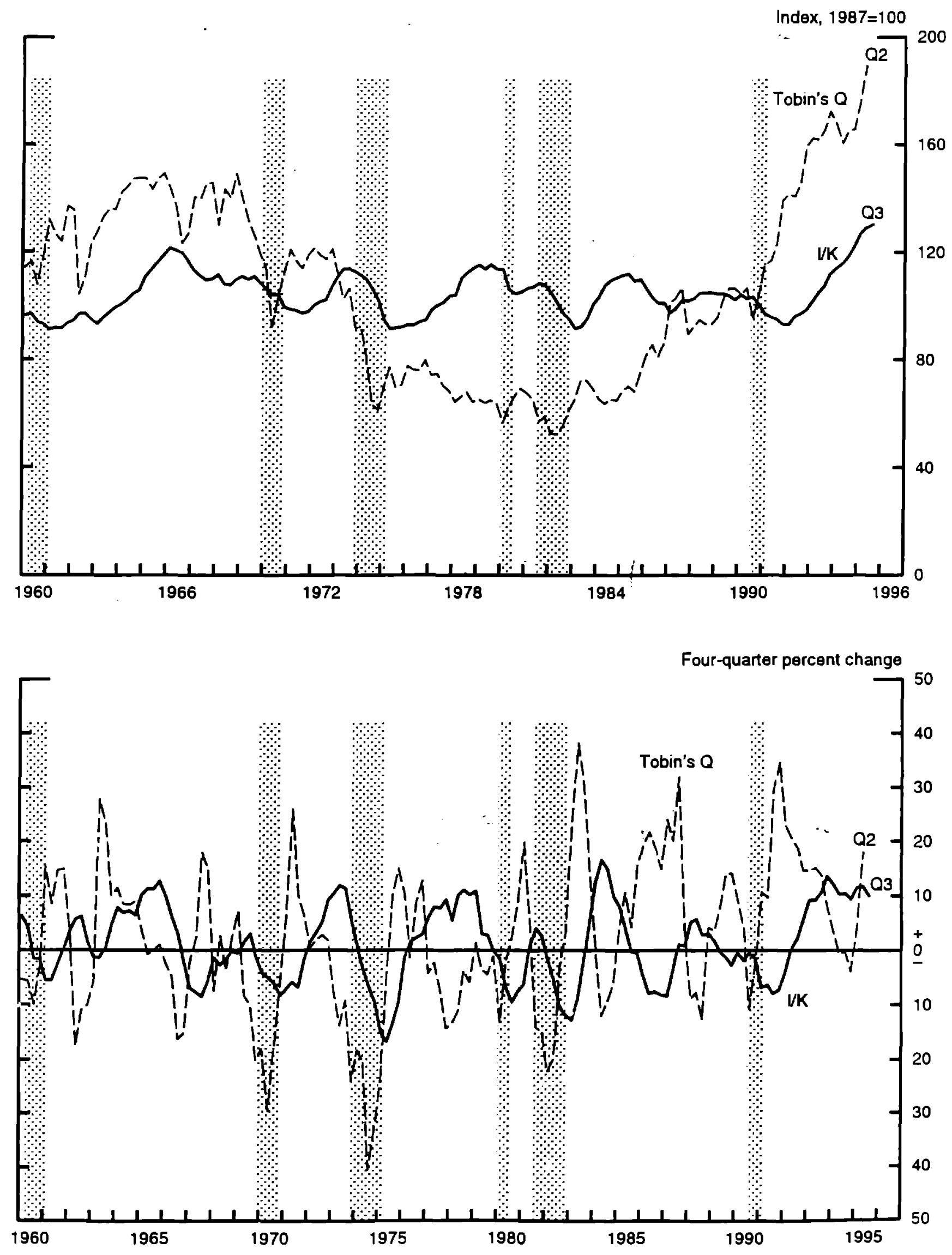


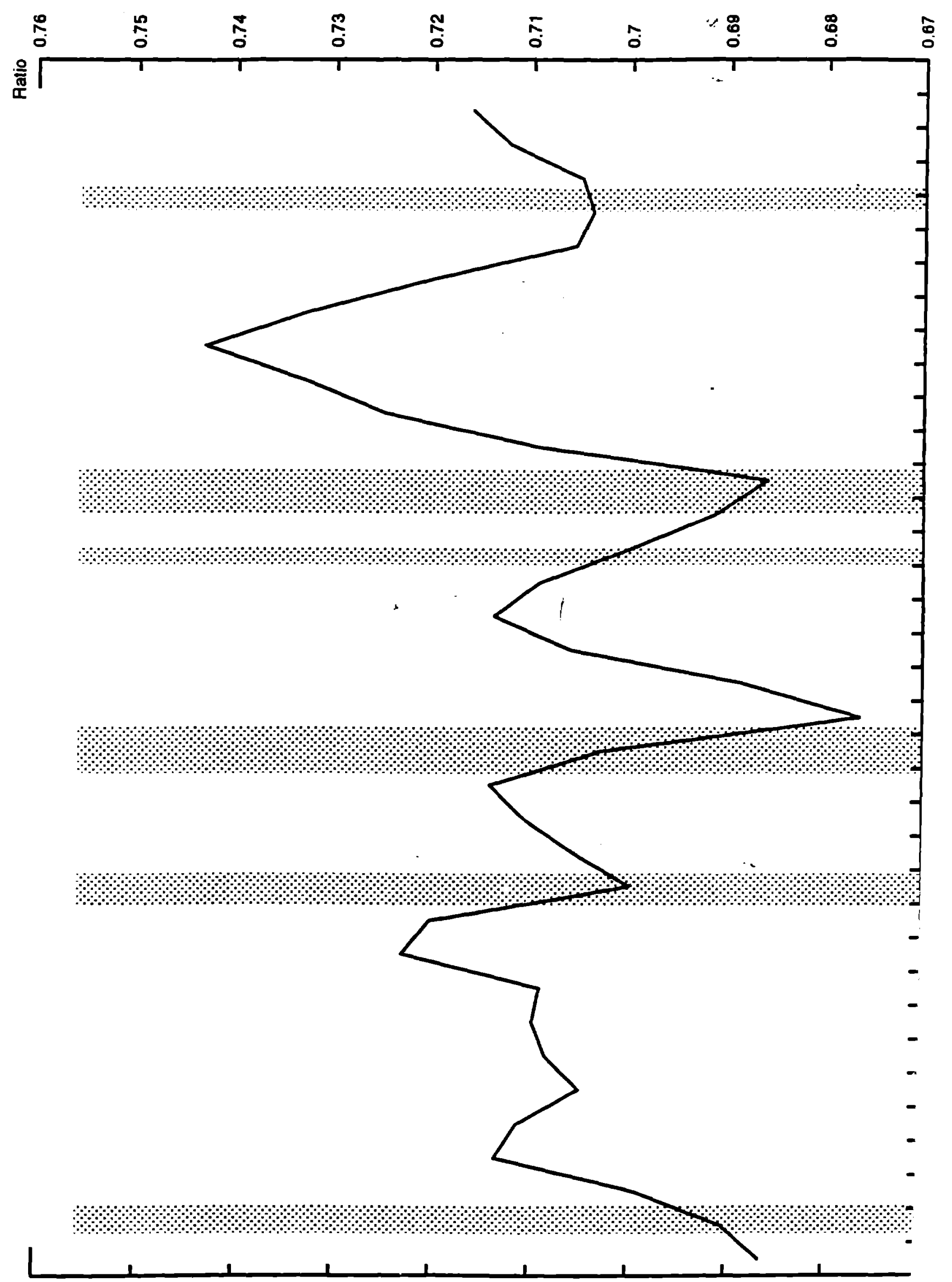


Figure 5. After-Tax Cost of One Dollar of Equipment Investment, 1953-89

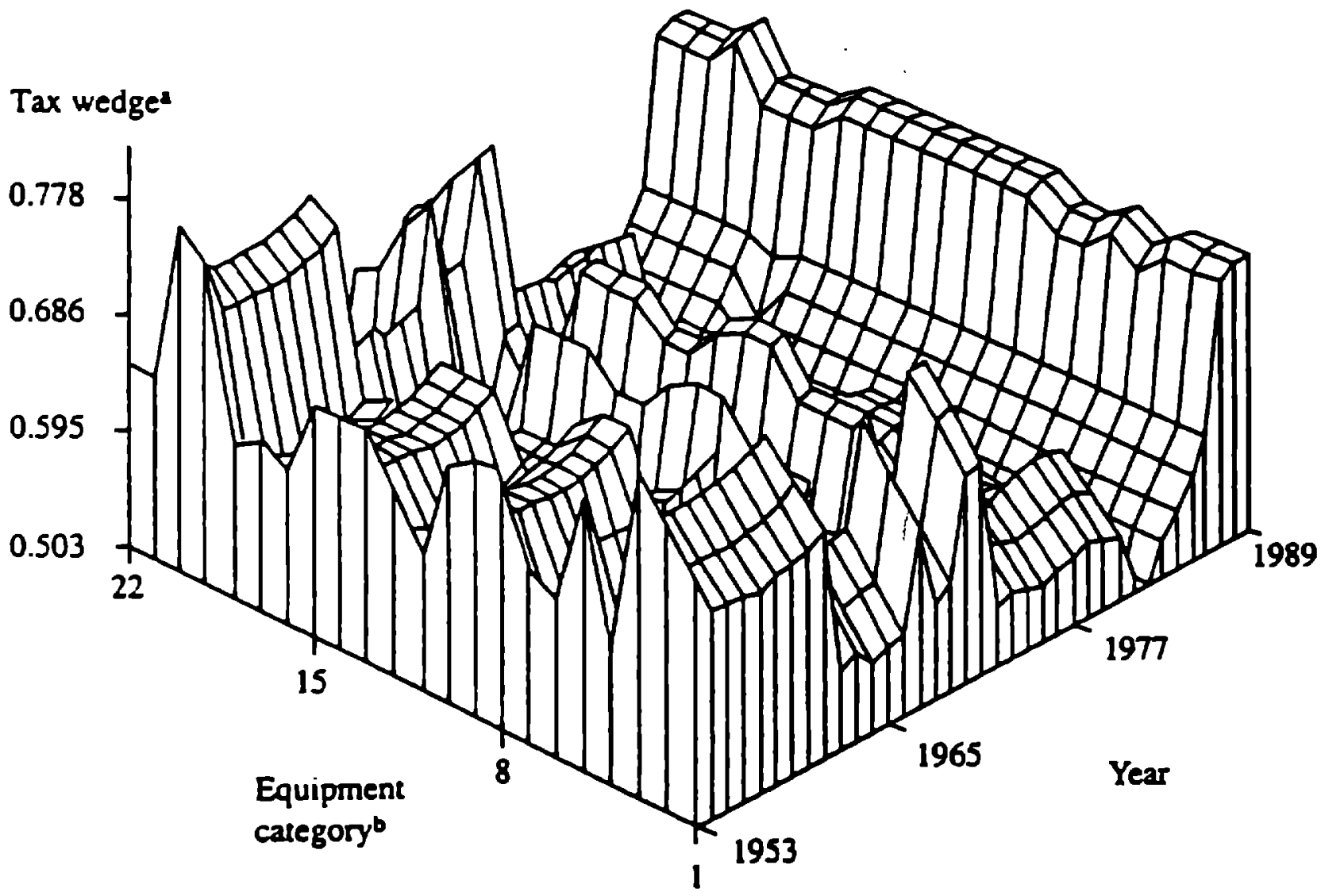

Source: Authors' calculauons based upon data from the Bureau of Economic Analysis.

a. The lax wedge is calculated from $r$. which is the sum of ine preseat value of tax savings from depreciation allowances and the investment tax credit. Higher values for $(1-n$ cortespond to higher after-12x costs of investipg. b. See iable 2 for BE.A classificauons. 


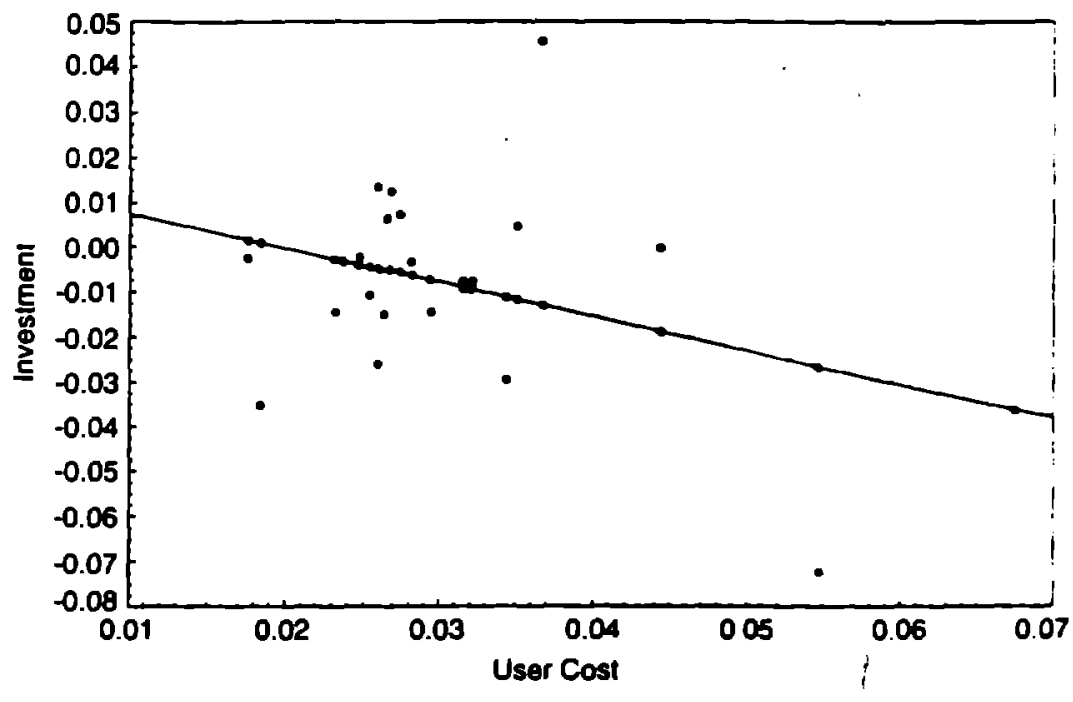

FIGURE 6. Cross-Sectional Relationship Between Investment and User Cost Forecast Errors: 1987.

Source: Cummins, Hassett, and Hubbard (1995, Figwe 3). 